SCIREA Journal of Economics

http://www.scirea.org/journal/Economics

October 28, 2021

Volume 6, Issue 5, October 2021

\title{
Globalization, Privatization and Population Decline in Eastern Europe: The Case of Serbia
}

\author{
Marija Obradović1 ${ }^{1, *}$, Nada Novaković ${ }^{2}$ \\ ${ }^{1}$ Institute for Recent History of Serbia, Belgrade, Serbia \\ ${ }^{2}$ Institute of Social Sciences, Belgrade, Serbia \\ *Corresponding author: m.obradovicinis1@gmail.com (Marija Obradović)
}

\begin{abstract}
In this paper, we provide the first evidence of a link between the policies of privatization and population decline in Eastern Europe. The globalization context is an opportune setting to investigate this link. Privatization is an integral element of transition, a part of globalization, conceptualized and managed by the World Bank, an international organization of financial capital.
\end{abstract}

Privatization led to an enormous increase in inequality in the distribution of wealth and income across the global economy.

In the USA and Western Europe, the working classes were rapidly and drastically impoverished, while in Eastern European countries' transition economies, they were almost entirely pauperized.

We identified a significant positive correlation between globalization, privatization, and the pauperization of the working class, with the outcome of population decline across Eastern 
Europe.This is especially visible in the territory of the former Yugoslavia where the breakup of the Socialist Federative Republic of Yugoslavia (SFRY) led to the cruel fratricidal war from 1991 to 1995.

This study aims to empirically examine a particular situation in Serbia and armed conflict in Kosovo from February 1998 to $11^{\text {th }}$ of June 1999. Demographic swing (population decline) is tracked by applying the concepts of Kuznetsov cycles and Malthusian waves, i.e., the movement of average income and inequality indices.

Keywords: Globalization, privatization,depopulation, Eastern Europe, Serbia

\section{Introduction}

The phenomenon of globalization "is the closer integration of the countries and people of the world with has been brought about by the enormous reduction of cost of transportation and communication, and the breaking down of artificial barriers to the flows of goods, services, capital knowledge, and (to a lesser extent) people across borders. Globalization has been accompanied by the creation of new institutions that have joined with existing ones to work across borders" ${ }^{1}$

Nevertheless, as Joseph Stiglitz explained, globalization has not succeeded in reducing poverty and ensuring stability in the world economy. "Globalization and the introduction of a market economy have not produced the promised result in Russia and most of the other economies making the transition from communism to market. ... Instead, it brought unprecedented poverty: in many respects, for most of the people..."2

The notions of 'transition,' 'transition economy,' and the 'age of transition' were developed in the 1960s by Marxist theorists. These notions described "transition from the capitalist mode of production to the socialist mode of production, that is, a country's passage from one period of the history of mankind to another, through an upheaval in production-relations and class relations and the replacement of one state machine by another with a different class

\footnotetext{
${ }^{1}$ Joseph E. Stiglitz, Globalization and Its Discontents, W. W. Norton \& Company, New York, London, 2003 , p.9

${ }^{2}$ Ibidem,p. 6
} 
nature". ${ }^{3}$ The complex structure and 'mixed' character of the system were emphasized as the main features of the world economy. "It is in the world economy there are 'combined' (in several dimension) the most diverse modes and systems of production and the various national economies which form parts of this complex totality". ${ }^{4}$

'A theory of transition' in the present essentially means a societal shift in a reverse direction accompanied by uniformity and a unipolar globalization-driven system of the world economy.

In basic terms, it is a reverse type of neoliberal transition and strategy of dependent modernization (neoliberalism) through which socialist socioeconomic systems are transformed into dependent types of societies on the margins of capitalism. The restoration of capitalism in Eastern Europe led to erosion of sovereignty, recolonization, marginalization, and states turned into protectorates. ${ }^{5}$

However, scientific papers based on neoliberal ideology speak of transition to democratic regimes and market economy. But, in general, "When we speak of the problem of transition, this phrase calls up the ideas of passing from one mode of production to another, of the constitution of a mode of production, of the transformation of an economic system, and so on." ${ }^{6}$

The central institutions governing globalization, transition, and privatization, as its key part, are The International Monetary Fund (IMF), the World Bank, and the World Trade Organization (WTO). ${ }^{7}$

\footnotetext{
${ }^{3}$ Charles Bettelheim, The Transition to Socialist Economy, Translated from the French by Brian Pearce, Sussex, The Harvester Press Limited, 1968, p.13

4 Ibidem,p.18

5 Ljubiša R. Mitrović, In the Role of Transition: between sunset and alternatives ( The pace of transition for transition and alternative society), Univerzitet u Nišu, Filozofski fakultet, Prometej, Niš, Novi Sad, 2017, p. p. 110, 186

6 Ibidem, p.19

7The World Bank ran privatization all by itself in Eastern European countries through privatization agencies by approving the selection of individual international investment banks as advisors and investment consultants as well as donations for expert assistance in privatization.(Dokumenti Agencije za privatizaciju Republike Srbije, avgust 2001.).
} 


\section{Globalization and inequality}

According to the World Bank nearly half of the world's population lives on less than 5.50 USD a day.

The crucial consequence of economic globalization is the reduction of global inequality across various world economies followed by the growth of income inequality across individual economies of nation-state. ${ }^{8}$

Globalization had increased wealth and income distribution inequality as a crucial characteristic of the national and global capitalist economy. To rephrase, private rate of return on capital is higher than the growth rate of income and production $(r>g)$. Once created, capital self-reproduces faster than production increases. This is the fundamental systemic contradiction of capitalism. $^{9}$

Simply put, this is a cornerstone of the enormous structural distortion accumulated throughout the existence of the capitalist system.

A significant part of social inequality is created via redistribution of income via rent. In rentseeking economies, private income and societal income are strongly opposed. “...rent-seeking defines the way by which many in our political sphere assist the wealthy to enrich at the expense of others, including transfers and state subsidies, the passage of laws reducing market competition, enabling executives of large enterprises to appropriate inestimable shares of profit as well as... laws enabling companies to profit while destroying natural habitat... The financial industry, which now functions mainly as a speculative market rather than a tool for stimulation of actual economic productivity, is the supreme example of a rent-seeking sector... Lately, $40 \%$ of corporate profits are absorbed by the financial sector" ${ }^{10}$

Thus, the financial sector absorbs a large percentage of corporate profits from varied economic activities via credit without contributing to the increase of real investment, which would lead to higher wages and sustainable growth, creates a speculative bubble, and inflates real estate prices. This explains why despite enormous growth in relation to wealth and income, median

\footnotetext{
${ }^{8}$ Branko Milanović, Global Inequality. A New Approach for the Age of Globalization, Harvard University Press, London, 2016

${ }^{9}$ Toma Piketi, Kapital i XXI veku, Akademska knjiga, Novi Sad, 2015

${ }^{10}$ Džozef E. Stiglic, Velika podela, Akademska knjiga, Novi Sad, 2015, p.p. 101,102
} 
income stagnates while actual return on capital does not fall. According to standard economic law, the law of diminishing returns, return on capital should fall, and wages should rise.

The historical era between 1988 (fall of the Berlin Wall) and the first global financial crisis (1997-1998) can be defined as the age of 'high globalization'). China integrated into the global economy with its one billion citizens, followed by former socialist successor states of the Soviet Union, adding about half a billion. This was also the era of revolutionary telecommunications technologies allowing companies to shift manufacturing plants to distant countries, availing themselves of the advantages of cheap labor without risking the loss of management control.

We witnessed the double coincidence of opening peripheral markets and circumstances allowing the countries of the center to engage the workforce of peripheral countries where they lived. This was the age of encompassing globalization that had never before existed in the history of the world. Globalization slows down afterward, particularly after the second global financial crisis in 2007-2008.

Although it led to the decrease of global income inequality, the benefits of this process were not distributed evenly. Chief beneficiaries of globalization were the capitalist classes in the countries of the center (global plutocrats). Their incomes rose significantly between 1998 and 2008. Here we find the US capitalists and big capitalists from Western Europe, Japan, Oceania, Brazil, South Africa, and Russia. Some benefits accrued with working classes of Asian countries, China, India, Thailand, Vietnam, and Indonesia. These countries also show a decrease in inequality. Globalization's biggest losers were the working classes in the countries of the center (USA, Western Europe), while the working classes of Eastern European countries were entirely pauperized with inequality reaching extreme levels. ${ }^{11}$

For the first time in the history of globalization, the economic conversion led to the decrease of global income inequality between states at the international economic level. In contrast, inequality rose on the national level in some peripheral countries and those of the center. However, this did not lead to the decrease of the significance of rent, above all because of the complete pauperization of the working class in the peripheral economies of Eastern European nations.

\footnotetext{
${ }^{11}$ Branko Milanović, Globalna nejednakost, Akademska knjiga, Novi Sad, 2016
} 


\section{The important questions in terms of the determinants and outcomes of privatization}

Three main theoretical perspectives have been used to support the privatization drive: property right theory, agency theory, and public choice theory. The basic assumption of these theories is that free-market forces enhance efficiency in the organization.

Theorists, governments, politicians have given the following reasons, and national and international institutions to justify privatization processes: enhancing efficiency through the introduction of competition and by obtaining resources in financial markets; reducing the deficit and the public debt; decreasing trade union influence; transferring the decision-making process in the market of goods and services from the public to private sector; encouraging popular capitalism; empowering employees by selling them company shares; redistributing social wealth and the modifications in the corporate governance system during the privatization process.

Privatization has been seen as one of the most important channels for improving corporate governance, which is crucial for enhancing economic efficiency and investor confidence. The critical aim of the privatization policy should be to boost the development of the corporate governance system.

Privatization, "as the deliberate sale by a government of state-owned enterprises (SOEs hereafter) or assets to private economic agents, is often implemented to restructure SOEs."12 Restructuring of state-owned enterprises is a part of their privatization.

Privatization has also been instrumental in reducing state ownership and has encouraged capital and labor to relocate from industry toward services in many countries. ${ }^{13}$ The SOEs share of 'global GDP' has declined from a little over nine percent in 1978 to perhaps six percent in $1998 .{ }^{14}$ The idea of privatization has been an essential part of an intellectual

\footnotetext{
12 Narjess Boubakri, Jean Claude Cosset, Walid Saffar, „The role of state and foreign owners in corporate risk-taking: Evidence from privatization “, Journal of Financial Economics 108, 2013, p. 642

${ }^{13}$ Martha de Melo, Cevdet Denizer, Alan Gelb, From Plan to Market Patterns of Transition, Policy Research Working Paper, The World Bank, Policy Research Department, Transition Economics Division, January, 1996

${ }^{14}$ William L. Megginson, Michael F. Price, Jeffry M. Netter, „From State to Market: A Survey of Empirical Studies on Privatization “, Global Equity Markets, A joint conference of the SBF Bourse de Paris and the New York Stock Exchange, Paris, France, December 10-11, 1998, p.43
} 
campaign against socialism during the eighties.

Over the past decades, privatization, a worldwide phenomenon, has become an important area for theoretical and empirical research. Since the beginning of this process in the eighties, there have been numerous studies about the privatization policies carried out in different countries. An extensive amount of literature has focused on the impact of privatization reform, defined as the sale of public assets and state-owned firms to the private sector at the micro-level.

The term privatization also refers to procedures through which a government transfers ownership of assets and control of commercial activities to the private sector. Privatization includes three types of procedures: outright sale of companies or assets, deregulation, and contracting out of service to private providers. The quantity of privatization is the number of transactions, and the quality is the sale value of the transaction.

The first generation of literature focused on the effect of privatization policies on the performance of former SOEs, their corporate governance structure, productivity, their pricing, etc. Recent studies on privatization took it to the next level and tried to examine other issues related to macroeconomic indicators by investigating whether privatization triggered changes in budget deficits, institutional indicators, stock market development, government bond spread and yields, and economic growth.

The privatization of SOEs has become a standard process worldwide and was considered a major component of New Public Management (NPM). In the framework of this doctrine, privatization is expected to correct inefficiencies associated with the public sector. However, privatization generally causes the firm to reduce its direct employment level. The vast majority of newly privatized firms (NPFs) experienced significant declines in employment and leverage. For example, after restructuring and privatizing FerrocarillaArgentinos, the Argentine national freight and passenger railway system, there was a $78.7 \%$ decline in employment, from 92,000 to $18,000 .^{15}$

The current debate among economists and policymakers about the effects of privatization has been ongoing. The relationship between the change of ownership, privatization, and

\footnotetext{
${ }^{15}$ William L. Megginson, Michael F. Price, Jeffry M. Netter, „From State to Market: A Survey of Empirical Studies on Privatization", Global Equity Markets, A joint conference of the SBF Bourse de Paris and the New York Stock Exchange, Paris, France, December 10-11, 1998, p.19
} 
performance is not clear. There are no significant findings that privatized companies in developing countries automatically improve their financial performance. The results of empirical studies of the effect of divestment on the operating performance of former SOEs are mixed.

The financial (profitability, employment, efficiency, investment, leverage, output, management, and dividends) and non-financial performances (e.g., quality and effectiveness) have not been analyzed by a sufficient number of empirical studies. Insufficient research analyzed the impact of large-scale privatizations on the level of development of a country. Also, there are is no social cost-benefit analysis of restructured and privatized companies. There are many open questions about the public welfare in the privatization process, the costs, benefits, and losses for the producers, employees, shareholders, governments, and consumers.

The findings of some of the most influential studies indicate that the method of privatization and the level of development of the country, institutional infrastructure, and governance mechanisms are the determinants of the performance of privatized companies.

In developing economies, privatization is a complex economic and political process. Privatization programs are much larger than in developed countries, and these processes are part of a broader reform of the political and economic system.

The privatization process in developing countries is complex due to underdeveloped institutional infrastructure, lack of effective governance mechanisms, and the lack of financial capital. In the Socialist Federative Republic of Yugoslavia (SFRY), for example, towards the end of 1989 , collective property made up over $90 \%$ of the capital value, while the total socially-owned capital was estimated at 250 billion USD, savings making up 13 billion USD or about $5 \%$ of the total socially-owned capital. "Lack of capital and buyer readiness for privatization is a strong constraint to ownership transformation in socialism."16

On the other hand, mass privatization is destructive due to its shock to existing institutions, political, economic, and relational.

An empirical analysis of the results of neoliberal 'shock doctrine' in 12 post-communist countries and two reformed Asian communist countries, one that takes for granted a radical

\footnotetext{
${ }^{16}$ Marija Obradović, Hronika tranzicionog groblja. Privatizacija društvenog kapitala u Srbiji 1989-2012. Nova srpska politička misao, Institut za noviju istoriju Srbije, Beograd, 2017, p.41
} 
transition towards market economy through rapid general price liberalization, free trade, monetary and fiscal stabilization measures, and implementation of the mass privatization program, by Lawrence P. King, concludes that the result is an adverse shock for enterprises which forces them to close. In turn, this led to a fiscal crisis of the state apparatus and erosion of its managerial capacity. The state could not support the institutions necessary for a capitalist economy to function. ${ }^{17}$

Contrary to neoclassical sociology, the neoliberal theory highlights that the failure of postcommunist economic transition is the consequence of failure to follow the rules of neoliberalism.

The variance between government controls and regulations in developing and developed countries can explain why privatization outcomes are different in these two types of countries. SOEs in developing countries do not have sufficient resources due to the weak state institutions which underfund infrastructure. The companies are more vulnerable to the corruption of their governments. The entire privatization process is less transparent, sometimes even linked to assassinations of the journalists covering it. ${ }^{18}$

On the one hand, some empirical study results show a positive and significant coefficient for the method of privatization in the profitability and efficiency models, which means that this variable is correlated with performance. Therefore, the method of privatization is an explanatory factor of post-privatization performance, and companies privatized via public offerings of state-owned enterprises by initial public offering (IPO) prices obtain better profitability and efficiency than those privatized via other methods.

Research conclusions from multiple sources emphasize that companies privatized through public offering end up with better performance than companies privatized via other methods, such as private sale or voucher privatization. Nevertheless, IPOs are a more effective method of privatization than private sales and vouchers for improving firm performance only if the stock market is developed. Because the IPO method of privatization of SOEs has prevailed in

\footnotetext{
${ }^{17}$ Lawrence P. King, Explaining Postcommunist Economic Performance, The William Davidson Institute, The University of Michigan Business School, Working paper Number 559, May , 2003.

${ }^{18}$ Veran Matić, chairman of the Republic of Serbia's government commission for investigation of the unsolved murder cases of journalists, published an open letter (dated June 10th, 2021, the tenth anniversary of the murder) posted to javniservis.net, linking the death of Milan Pantić, a correspondent journalist for Večernje Novosti from Jagodina, reporting on the privatization of the cement plant Novi Popovac in Paraćin.
} 
developed countries and methods of direct sale and vouchers in developing countries,privatization through IPO's plays an active role in corporate governance. Governments structure IPOs to maximize political and economic benefit at the expense of revenue maximization and care whether their citizens have a positive investment experience after purchasing shares of SOEs being privatized. However, results indicate that companies privatized via IPOs invest less than companies privatized by private sales.On the other hand, there is abundant evidence on average that IPOs are underpriced, providing significant initial returns to investors who can buy shares at the initial offer price. ${ }^{19}$

Because the cumulative evidence is not conclusive, the question of the privatization/performance relationship remains open. Despite the multitude of studies on the relationship between the change of ownership and financial performance, the lack of consensus on the outcomes leaves the debate open.

We find the same situation regarding the results of empirical research on the impact of mass privatization on stock market size and liquidity and the creation of financial and capital markets in developing countries. The common assumption that privatization does not improve financial performance in developing countries has been widespread.

The evidence shows that privatization performance is better in countries where developed stock markets exist. In the vast majority of developing countries, the policy of privatization has been pursued while no efficient markets existed for the shares being offered.

For example, mass privatization in Russia and the Czech Republic has not created sustained levels of high economic growth, and that the development of capital markets has also disappointed expectations. In the absence of institutional mechanisms of state regulation and trust, markets become arenas for the political contest and economic manipulation. ${ }^{20}$

\footnotetext{
${ }^{19}$ Kathryn L. Dewenter, Paul H. Malatesta, „Public Offerings of State-Owned And Privately-Owned Enterprises: An International Comparison”, The Journal of Finance Vol. LII, NO 4, September 1997, p. 1660

${ }^{20}$ Bruce Kogut, Andrew Spicer, Institutional Technology and the Chains of Trust: Capital Markets and Privatization in Russia and the Czech Republic, William Davidson Institute Working Paper Number 335, August, 2000, p. 3
} 
Because most MENA countries' state-owned firms were sold through private sales, most privatization transactions were completed outside the stock market. Therefore, no positive externalities for the stock market could be found. ${ }^{21}$

Most studies on the determinants of privatization indicate that macroeconomic crises, as evidenced by hyperinflation and severe balance of payments, are the main reasons why governments privatize SOEs.

Privatization is frequently implemented when bad economic conditions, high foreign debt, high dependence on international agencies, and budget deficits prevail. Some studies indicate that high government debt is a crucial determinant of privatization. These studies reported that positive inflation was significantly correlated with privatization policy. Privatization policy was much more likely to be crisis-driven, as a last-ditch effort to turn the economy around, rather than a product of carefully chosen policy with explicit long-term goals. Some governments have raised significant revenues through the sale of SOEs. The short-term goal of revenue generation is the driver of privatization, to overcome fiscal crises, rather than the long-term goals of economic development. The reason being that privatization is more of a political decision than an economic one. Therefore, the extent of privatization depends on the level of democracy or the governing party's ideology. Right-wing governments or marketoriented governments are more likely to privatize than left-wing or centrist governments oriented toward central planning. ${ }^{22}$

An analysis of operational and restructuring indicators shows that the privatization of stateowned enterprises in Italy between 1993 and 2003 did not increase their efficiency or raise the general liquidity level in the country. ${ }^{23}$

\footnotetext{
${ }^{21}$ Samy Ben Naceur, Narjess Boubakri and Samir Ghazouani, „Privatization and Financial Market Development: A Comparison Between MENA Countries and Other Regions", Working paper No.390, Economic Research Forum, April, 2008, p.13

${ }^{22}$ Samuel Adams, Berhanu Mengistu, „The Political Economy of Privatization in Sub-Saharan Africa”, Social Science Quarterly, Volume 89, Number 1, March, 2008, p.p. 82, 83,86,87,88.

${ }^{23}$ Andrea Goldstein, Privatization in Italy 1993-2002: Goals, Institution, Outcomes, and Outstanding Issues, CESIFO , Working Paper No. 912, Category1: Public Finance, April 2003, Presented at CESIFO Conference "Privatization Experience in the EU, January, 2003.
} 
Analysis of newly privatized firms in Poland, Hungary, and the Czech Republic from 1990 to1998 shows no significant improvement of business operation when productivity, investment, and efficiency are considered, but there was a drop in unemployment. ${ }^{24}$

However, there are no rigorous econometric analyses on the relationship between income inequality, total external debt as a percentage of gross domestic product (GDP), and the implementation of privatization.

\section{Globalization and privatization}

Thousands of SOEs have been turned over to the private sector in Western Europe, Latin America, Asia, Africa, and Eastern Europe since the 1980s. More than 100 countries have undertaken privatization programs since the mid-1980s. Forty years ago, privatization became an essential global economic phenomenon. Since the Thatcher government first launched largescale privatization in the United Kingdom, approximately 1.25 trillion USD has been raised. Moreover, share issue privatizations (SIPs) accounted for 750 billion USD between 1980 and $2000 . .^{25}$

The worldwide total sales of SOEs already topped 185 billion USD by 1990 . Governments raised over two-thirds of a trillion dollars through share offerings and direct sales (excluding voucher privatization) since $1977 .{ }^{26}$

In the early to mid-1990s, privatization proceeds in developing countries averaged 20 billion USD annually.

In 1997, proceeds increased, reaching 70 billion USD due to increased expansion in large infrastructure and energy transactions, mainly in Latin America (Argentina, Brazil, and Mexico), Kazakhstan, Russia, and China. Following the East Asian crisis of 1997 and the

\footnotetext{
${ }^{24}$ Wolfgang Aussenegg, Ranko Jelić, "The Operating Performance of Newly Privatized Firms in Central European Transition Economies", European Financial Management, Vol. 13 No. 5, 2007.

25 Samy Ben Naceur, Samir Ghazouani, Mohammed Omran, „The performance of newly privatized firm in selected MENA countries: The role of ownership structure, governance and liberalization policies", International Review of Financial Analysis 16 (2007), p.333

${ }^{26}$ William L. Megginson, Michael F. Price, Jeffry M. Netter, „From State to Market: A Survey of Empirical Studies on Privatization", Global Equity Markets, A joint conference of the SBF Bourse de Paris and the New York Stock Exchange, Paris, France, December 10-11, 1998, p.9
} 
Russian debt crisis of 1998, privatization revenues plunged. However, in 2002 proceeds reached their pre-1997 level mainly from share sales in telecoms and banking in China, Czech Republic, Slovakia, India, and Saudi Arabia. ${ }^{27}$

In the 1990s, governments of 59 countries privatized 250 commercial banks fully or partially either through IPOs or privately through an asset sale. ${ }^{28}$

Throughout the world, annual revenues from privatization soared during the late 1990s, peaking in 1998 at over 100 billion USD. Industrial countries have pursued privatization less vigorously than have developing countries. Between 1984 and 1996, the participation of SOEs in industrial countries declined from the peak of $8.5 \%$ to about $5.0 \%$ of gross domestic products (GDP), while production from state-owned companies declined more steeply in developing countries. The activities of SOEs as a percentage of GDP decreased from about 11 percent in 1980 to 5 percent in 1997 in middle-income countries and from 15 to $3 \%$ in lowincome countries. Developing countries also saw significant reductions in employment among SOEs during the same period. In middle-income countries, employment in SOEs fell from a peak of 13 percent of total employment to about $2 \%$, and in low-income countries, it dropped from more than 20 percent to about $9 \%$.

In the 1980s, several Latin American countries launched significant privatization programs, especially Argentina, Brazil, Chile, and Mexico. In the 1990s, Eastern European postcommunist economies have been highly active in privatization. Latin America accounted for $55 \%$ of total privatization revenues in the developing world in the 1990s. Transition economies in Eastern Europe and Central Asia accounted for $21 \%$ of total privatization revenues in developing countries during the 1990s, second only to Latin America.

Towards the World Bank, proceeds from privatization in developing countries, 1990-99 were 44.100 billion USD in East Asia and Pacific, 177.839 billion USD in Latin America, 65.466 billion USD in Eastern Europe and Central Asia, 8.197 billion USD in the Middle East, and

\footnotetext{
${ }^{27}$ Samy Ben Naceur, Samir Ghazouani, Mohammed Omran, „The performance of newly privatized firm in selected MENA countries: The role of ownership structure, governance and liberalization policies", International Review of Financial Analysis 16 (2007), p.334

28 W. L. Megginson, The Financial Economics of Privatization, Oxford University Press, USA, 2005
} 
North Africa, 11.854 billion USD in South Asia, and 8.264 billion USD in Sub-Saharan Africa. ${ }^{29}$

The four Middle Eastern and North African (MENA) countries, Egypt, Morocco, Tunisia, and Turkey raised 19 billion USD or $5 \%$ of their total privatization proceeds from 320 transactions. In the 1990s, privatization revenue was highly concentrated in two countries: Egypt (50 \% of the region's proceeds) and Morocco (40\%). Transactions in both countries were mainly in manufacturing, although Morocco's proceeds included revenue from energy and banking privatization. In early 2000 , the telecommunications sector was the leading sector in the privatization program in the MENA region. ${ }^{30}$

Developing countries carried out more than 9,000 privatization transactions and raised nearly 410 billion USD in privatization revenues between 1988 and 2003. Though privatization activity increased in all developing world regions, proceeds are highly concentrated in Latin America and East Asia. Latin America accounted for 64 percent of total privatization proceeds, with $39 \%$ of the total number of transactions, followed by East Asia with 21 percent of the privatization proceeds and $13 \%$ of the transactions. In comparison, Sub-Saharan Africa (SSA) accounted for $27 \%$ of transactions but only $4 \%$ of proceeds. The low privatization revenues in SSA are because of the nearly 2,300 privatization transactions between 1991 and 2001, and only 66 involved higher value and economically viable firms. Almost a third of the privatization revenues were generated in South Africa and another third from only four countries: Ghana, Nigeria, Zambia, and the Ivory Coast. Most studies show that privatization in SSA began to pick up in the late 1980s and peaked at the end of the 1990s. ${ }^{31}$

Many countries launched neoliberal economic reform programs to foster private sector development, mainly through the privatization of SOEs. These programs' primary aim is to decrease government control in the economy and transfer the ownership of former SOEs from the state to private investors.

\footnotetext{
${ }^{29}$ Alberto Chrong and Florencio Lopez-de-Silanes, "The Truth about Privatization in Latin America", Privatization in Latin America, edited by Alberto Chong, Florencio Lopez-de-Silanes, Stanford University Press and the World Bank, 2005, pp. 3-5

${ }^{30}$ Samy Ben Naceur, Samir Ghazouani, Mohammed Omran, „The performance of newly privatized firm in selected MENA countries: The role of ownership structure, governance and liberalization policies", International Review of Financial Analysis 16 (2007), p.334

31 Samuel Adams, Berhanu Mengistu, „The Political Economy of Privatization in Sub-Saharan Africa”, Social Science Quarterly, Volume 89, Number 1, March 2008, p. p. 78,79
} 
When countries promote economic policies favoring private ownership, they simultaneously attract the attention of foreign investors, either multinational corporations in the form of foreign direct investment (FDI) or individual and institutional investors in the form of foreign portfolio investment (FPI). Portfolio investors are mainly profit-motivated, whereas direct investors seek to exert asset control.

The World Bank (2003) notes that FDI has become the most significant and most resilient form of capital flow in developing countries.Privatization impacted foreign investment in many Latin American countries, where the increase of foreign capital has been accompanied by a decline in state involvement in the economy. Up to the financial crisis in 1997, foreign investor participation in privatization in Argentina was 65\%; in Brazil 43\%; in Chile 50\%; and in Mexico 7\%. In Argentina, foreign investor's participation in privatization of the financial sector was as high as 90\%; in Brazil, in gas extraction, $97 \%$, and $72 \%$ in telecommunications in Mexico. ${ }^{32}$

In its 2008 Global Development Finance, The World Bank notes that the surge in FDI inflows to Europe and Central Asia in 2007 was associated with privatization programs, as was the case for the large volume of FDI inflows to Latin America in the late 1990s.

Like privatization, FDI, and FPI, two proxies of globalization witnessed significant and steady progress worldwide. The rising trend in FDI around the globe is analyzed in several World Bank reports. Notably, the World Bank (2002) reports that FDI has positively responded to government implementations of privatization programs and notes that seven of the ten largest FDI recipients received more than 1 billion USD from foreign investors to participate in the privatization transactions conducted in 1999. The intensity of the privatization program seems to be strengthened by massive increases in FDI flows which continued to increase throughout the 2000s. The World Bank reports that net portfolio equity inflows to developing countries increased dramatically over the recent period: from 11 billion USD in 1999 to 145.1 billion USD in 2007. The joint foreign investment inflows (direct investment and portfolio investment)

\footnotetext{
32 INDEC (1998), BNDES (1998, 1999), CORFO, J. Rogozinsjki, La privatizaciun en Mexico: razons v impactos, Trillas, Mexico, 1997
} 
to developing countries totaled 536 billion USD in 2008, down $19 \%$ from 664 billion USD recorded in 2007 when the financial crisis started..$^{33}$

Privatization has an effect on globalization as the policy of fostering private sector participation often involved the allocation of substantial shares to foreign investors in NPFs.

FDI flows have accompanied and responded positively to government privatization programs in developing countries. The intensity of privatization programs seems to have been strengthened by massive increases in FDI flows which continued to increase throughout the 2000s.

Globalization was spurred through FDI, independent of the launch of the privatization programs. In other words, FDI in developing countries is the link between privatization and globalization.Because privatization is attracting FDI, it is a determinant of globalization; in turn,globalization was enhanced and contributed to the sustainability of the privatization process.

\section{'Privatization trap' and population decline in Eastern Europe}

Globalization and large-scale privatization did not bring prosperity to the post-communist countries of Eastern Europe. The main socio-economic consequences of the historical processes discussed were the pauperization of the entire working class and significant population drops in these countries. If we can say that the international financial capital is the globalization winner, the eastern European working class is its biggest loser.

\footnotetext{
${ }^{33}$ Narjess Boubakri, Jean Claude Cosset, Nassima Debab, Pascale Valery, „Privatization and Globalization: En Empirical Analysis", Centre Interuniversitaire sur le Risque, les Politiques Economiques et 'Emploi (C I R P E E), Cahier de recherche/Working Paper 11-30, September 2011, p.p. 1,2
} 


\section{GLOBALIZATION}

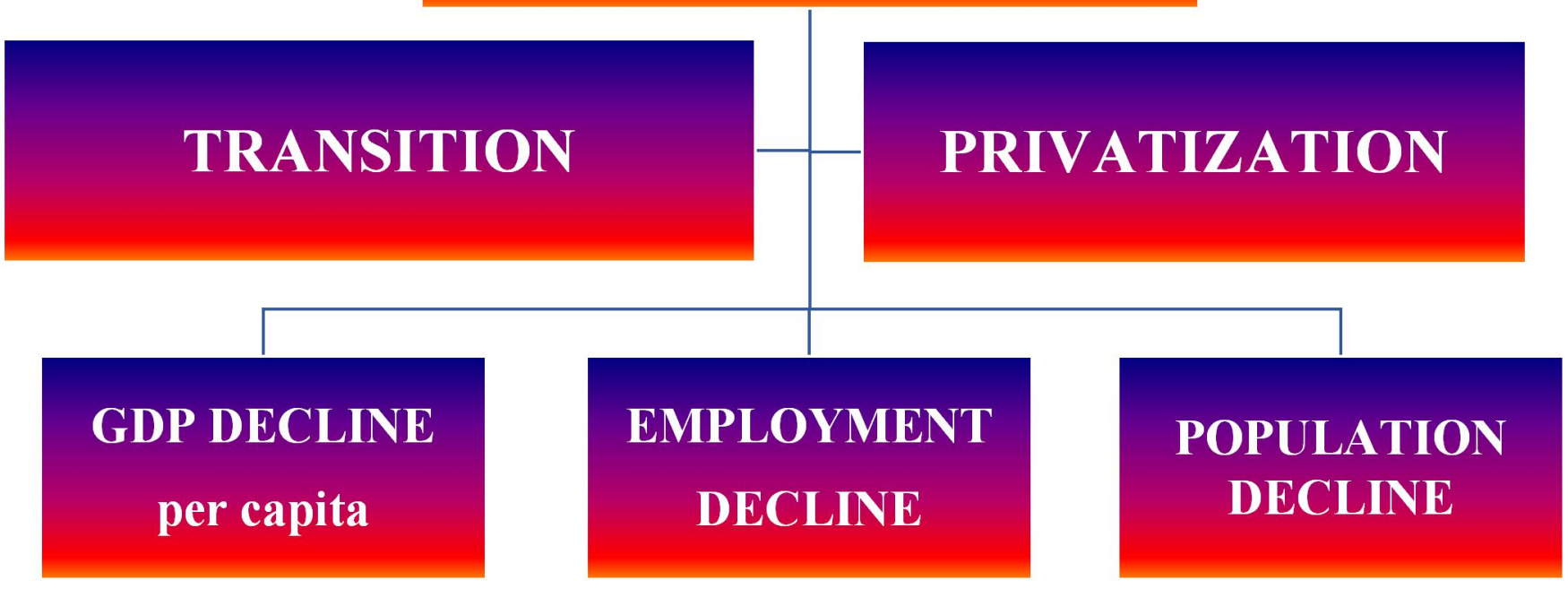

Fig 1 Model of the recent population decline in Eastern Europ

Critics of privatization often argue that the government, and thus society at large, loses through privatization because it gives up positive cash flow streams and transfers them to private buyers. The argument is extended to claim that the sale of SOEs is equivalent to the privatization of gains and socialization of losses. In other words, well-connected groups can reap the profits of privatized firms and receive government-sponsored bailouts when things go wrong.

The bailouts granted in Mexico to prevent the bankruptcy of banks and highways increased the public debt from less than $25 \%$ of GDP to over $50 \%{ }^{34}$

The studies show that regulations were purposefully drafted to allow national economic groups with access to foreign credit and liquid assets to benefit from privatization assisted by

${ }^{34}$ Alberto Chrong and Florencio Lopez-de-Silanes, "The Truth about Privatization in Latin America", Privatization in Latin America, edited by Alberto Chong, Florencio Lopez-de-Silanes, Stanford University Press and the World Bank, 2005, p. 27 
generous public subsidies. Policy implementation of privatization programs shows that the government's coalition-building strategy complemented economic incentives. The links between interest groups and policymakers are central to the understanding of why privatization occurred..$^{35}$

The economic effects of privatization of SOEs in the Central and East European and the Baltic (CEEB) countries and the Commonwealth of Independent States (CIS) have been the subject of intense re-examination. Especially in conflicting empirical results about the so-called Washington Consensus mantra that private ownership and market forces would ensure more efficient economic performance than socially owned enterprises and planning systems.

After the collapse of communism in 1989-91, all of the newly elected governments of the region adopted a privatization policy. In the late 1980s and early 1990s, the new policymakers in CEEB and CIS formulated strategies that focused on macroeconomic stabilization, microeconomic restructuring, liberalization, privatization, political and institutional reforms to support these strategies and dismantle the legacy institutions of the communist system. Most transition countries quickly reduced directtrust subsidies to SOEs and allowed them to restructure and even break up. ${ }^{36}$

However, political considerations required this government to introduce significant limits to foreign purchases of divested assets. Since the region had minimal financial savings, the governments throughout the region launched 'mass privatization' programs that generally involved distributing vouchers to the citizens who could use them to purchase shares in companies sold. Although this program resulted in a massive reduction of SOEs and the programs were initially immensely popular politically, the net effects of these programs remain poorly understood. ${ }^{37}$

The privatization process in CEEB and CIS was complex due to a week regulatory framework, an ineffective private sector, a low level of domestic income and savings, and the absence of adequate capital and stock markets. Sometimes even profitable companies could not be sold

\footnotetext{
${ }^{35}$ Sylvain Turcotte, Philippe Faucher, Haw Markets and Business Power Influenced Privatization in Latin America, February , 2002

${ }^{36}$ Jan Hanousek, Evzen Kocenda,Jan Svejnar, Privatization and Performance over the Transition: A Reassessment 2005.

37 William L. Megginson, Michael F. Price, Jeffry M. Netter, „From State to Market: A Survey of Empirical Studies on Privatization”, Global Equity Markets, A joint conference of the SBF Bourse de Paris and the New York Stock Exchange, Paris, France, December 10-11, 1998, p.6
} 
easily, and buyers paid minute amounts of money unless they were allowed to restructure the companies and to lay off workers. Restructuring implied asset stripping, which reduced the value of the company.

SOEs performanceduring the privatization was terrible. Profitability declined in companies slated for privatization, while balance sheets showed disinvestments or increased debt ratios. Employees became disengaged, and managers were frustrated because investments were restricted, and financing curtailed since the government was not interested in successful companies. The enterprises were neglected during the privatization process, and the institutional environment reduced the ability of managers to create value. The empirical findings suggest that the value of SOEs was destroyed in the privatization process, and the companies deteriorated economically. ${ }^{38}$ SOEs' performance declined, which made the companies less attractive to buyers in a continuing downward spiral phenomenon best summarized as the 'privatization trap. ${ }^{139}$

Privatization in Eastern Europe occurred under conditions of high inflation, and many privatized SOEs went bankrupt. The surveys about the effects of privatization on economic performance suggest that privatization by domestic owners has a limited impacton performance. Only privatization by certain types of foreign owners appears to improve the efficiency of firms. ${ }^{40}$

Privatization in Eastern European countries did not contribute to the efficiency of operation of the companies regardless of the method used vouchers, direct sale, or insider sale to management and employees (Management Buy-Out, MBO, and Management Employee BuyOut MEBO). The lowest improvement to productivity post-privatization occurred in

\footnotetext{
${ }^{38} \mathrm{~A}$ detailed description of this process with a plethora of original material from Serbia's Privatization Agency is found in Marija Obradović, Hronika tranzicionog groblja. Privatizacija društvenog kapitala u Srbiji 1989-2012. Nova srpska politička misao, Institut za noviju istoriju Srbije, Beograd, 2017.

${ }^{39}$ Stifanos Hailemariam, Henk von Eije and Jos van der Werf, Is there a 'Privatization Trap'? The Case of the Manufacturing Industries in Eritrea, January 2002, Source: RePEc, Research Gate.

40 Jan Hanousek, „The Effects of Privatization and Ownership in Transition Economies”, Journal of Economic Literature 47 (3) February ,2009.
} 
companies privatized in Ukraine and the Russian federation. Companies bought by foreign investors achieved somewhat better results in terms of productivity. ${ }^{41}$

An inflation increase followed privatization in Eastern Europe (1989-1994). Inflation reached 26.0 \% in Slovenia; 807.0 \% in Croatia; 157.0 \% in the Former Yugoslav Republic Macedonia; 34.0 \% in Poland; 21.0 \% in Hungary; 16.0 \% in Czech Republic; 19.0 \% in Slovakia; $81.0 \%$ in Bulgaria; 194.0 \%in Romania; 57.0 \%in Albania; and558.0 \%in Russian Federation.The GDP in Slovenia in 1994. was $84.0 \%$ of its GDP in 1989; in Croatia, it was $68.0 \% ; 55.0 \%$ in the Former Yugoslav Republic of Macedonia; 88.0 \% in Poland; 80.0 \% in Hungary; 81.0 \% in the Czech Republic; 77.0\% in Slovakia; 73.0 \% in Bulgaria; 67\% in Romania; 74.0 \% in Albania; $57.0 \%$ in Russia. The Russian Federation received a loan of 4,641.5 million USD at that time. ${ }^{42}$

Unemployment for the same period rose from $0.1 \%$ in 1989 to $15.7 \%$ in Poland; in the Czech Republic, from $0.0 \%$ to $3.0 \%$; in Slovakia, from $0.0 \%$ to $14.4 \%$; in Hungary from $0.3 \%$ to 12.1 \%; in Estonia, from 0.0 \% to 2.6 \%; in Latvia from 0.0 \% to 5.3 \%; in Russian Federation, from $0.0 \%$ to $5.5 \%$; in Belarus, from $1.0 \%$ to $1.5 \%$; and in Ukraine from $0.0 \%$ to $0.4 \%$.

Maximum intensity privatization in Russian Federation, Ukraine, and Belarus occurred between 1993 and 1994. The GDP in Russia decreased by 49.8 \% after privatization compared to 1990in Ukraine, GDP fell by $55.0 \%$, and by $37.4 \%$ in Belarus, which had the smallest volume of privatization by far.

The GDP in the Czech Republic, which had the most intensive privatization, dropped by 15.7 \% for the same period, while the GDP in Poland fell by 8.8 \%, in Slovakia, by $21.0 \%$; in Albania by 22.7 \%; in Estonia, the drop was 29.5 \%; in Latvia 43.0 \%; in Hungary, 19.0 \%; in Slovenia, $16.4 \%$; and in Lithuania, $55.5 \% .^{43}$

\footnotetext{
${ }^{41}$ Klaus E. Mayer, Privatization and Corporate Governance in Eastern Europe:The Emergence of Stakeholder Capitalism, Center for East European Studies, Copenhagen Business School, Keynote address Chemnitz East Forum, 19-20 March 2003 ). p.19

${ }^{42}$ Transition. The Newsletter about Reforming Economies, The World Bank, Volume 6, November 11-12, NovemberDecember 1995, p. 2; Martha de Melo, Cevdet Denizer, Alan Gelb, From Plan to Market Patterns of Transition, Policy Research Working Paper, The World Bank, Policy Research Department, Transition Economics Division, January 1996, p. 5

${ }^{43}$ Marek Dabrowski, Rafal Antczak, Economic Transition in Russia, the Ukraine and Belarus in Comparative Perspective, Center for Social \& Economic Research, Warsaw, July, 1995, p. p. 31, 38, 40
} 
Unemployment rose throughout the 2000s. In 2011 unemployment rate was $10.9 \%$ in Hungary; 10.8 \% in Slovenia; $15.6 \%$ in Lithuania; $13.0 \%$ in Latvia, and $12.1 \%$ in Estonia.

Youth unemployment (15-24 years) was far higher than the general rate at the national level in these countries. By 2014 it reached 28.0 \% in Bulgaria; 21.3\% in Czech Republic; 27.2 \%in Poland; 28.1\% in Hungary; 20.1 \% in Slovenia; 43.3 \% in Croatia; 55.8 in Former Yugoslav Republic of Macedonia; and $43.4 \%$ in Serbia.

The transition from the national-communist model of modernization to that of the dependent modernization based on globalization and privatization brought an enormous rise of foreign debt in Eastern Europe. In 2011 Hungary was 146 billion USD in debt, Poland owed 306 billion USD, Czech Republic 101 billion USD, Slovenia 61 billion USD, Slovakia 72 billion USD, Romania 136 billion USD, and Bulgaria 39 billion USD.

Unemployment and pauperization led to a vertiginous rise in the population living below the poverty level. The poverty level in Romania was 21.1 \%; in Hungary (2010), 13.9 \%; in Bulgaria (2008), $21.8 \%$; and in Estonia (2010), $17.5 \%{ }^{44}$

The monthly minimum wage in the EU countries ranges from 332 EUR in Bulgaria to 2,202 EUR in Luxemburg, according to the latest data from Eurostat, published in January 2021. By comparison, the minimum wage in the United States was 1,024 for January 2021.

The average minimum wage in Easter Europe was around 700 EUR, while it is 1,500 EUR in the northwestern countries of the union. The data for 21 countries with legislated minimum wage gives 442 EUR in Hungary; 458 EUR in Romania; 642 EUR in Lithuania; 500 EUR in Latvia; 584 EUR in Estonia; 563 in Croatia; 1,024 EUR in Slovenia; 579 EUR in the Czech Republic; 614 EUR in Poland; and 623 EUR in Slovakia.

Three decades after implementing neo-liberal stabilization programs and structural reforms (including the removal of price control, industrial restructuring, privatization of SOEs, and the creation of economies open to foreign investment) in Eastern Europe, belief in the material efficiency of the new system has fallen everywhere.

\footnotetext{
${ }^{44}$ Ljubiša R. Mitrović, In the Role of Transition: between sunset and alternatives ( The pace of transition for transition and alternative society), Univerzitet u Nišu, Filozofski fakultet, Prometej, Niš, Novi Sad, 2017, p. p. 38, 186, 187,188, 189
} 
Social costs of liberalization, structural reform, and privatization are expressed in lower incomes, higher inequality, greater poverty, rising unemployment, relative economic backwardness, destruction of property (privatized firms), an ever-increasing drift between the wealthy elites and impoverished masses, pauperization of the working-class and population shrinkage in Eastern Europe.

Present-day Eastern Europe is one of the areas with the highest levelsof emigration.

Table 1 Eastern Europe emigration rates based on the United Nations data in 2015

\begin{tabular}{|c|c|}
\hline Countries & Percentage* \\
\hline Russian Federation & $7.4 \%$ \\
\hline Ukraine & $13.0 \%$ \\
\hline Belarus & $15.6 \%$ \\
\hline Poland & $11.5 \%$ \\
\hline Hungary & $6.0 \%$ \\
\hline Romania & $17.5 \%$ \\
\hline Bulgaria & $16.5 \%$ \\
\hline Czech Republic & $8.8 \%$ \\
\hline Slovakia & $6.3 \%$ \\
\hline Lithuania & $18.9 \%$ \\
\hline Latvia & $17.1 \%$ \\
\hline Estonia & $15.1 \%$ \\
\hline Albania & $38.0 \%$ \\
\hline Slovenia & $6.8 \%$ \\
\hline Croatia & $20.4 \%$ \\
\hline Bosnia and Herzegovina & $43.4 \%$ \\
\hline Serbia & $10.9 \%$ \\
\hline Montenegro & $22.1 \%$ \\
\hline Macedonia & $24.8 \%$ \\
\hline
\end{tabular}

*Percentage calculations were based on the following: The population of Poland was $38,612,000$ in 2015, according to the United Nations data. The number of those born in Poland 
who lived in a different country was $4,449,000$. Therefore $38,612,000$ divided by $4,449,000=$ 11.5\%. Data is based on the place of birth, not citizenship or ethnic affiliation.

Emigration from the peripheral countries of Eastern Europe exceeds the emigration from the countries of the European center where it averages 3-8\% except in rim countries like Portugal $(22.3 \%)$ and the Republic of Ireland (18.8\%). ${ }^{45}$

Emigration is particularly intensive within the region of Yugoslavia. Croatia lost 200,000 citizens between 2013 and 2019; the population shrunk from 4,26 million to 4,06 million, as estimated by the national statistics. ${ }^{46}$

The principal causes of emigration, according to the annual research 'Balkanski Barometer' of the Regional Cooperation Council, are high unemployment, low wages, adverse economic conditions, and a significant increase in corruption perception. Almost every other citizen of Sarajevo, Zagreb, and Belgrade is ready to depart from his country to seek employment.

"According to the research of the Balkan barometer, dissatisfaction with the institutions and lack of confidence in the state is a universal outcome for all countries in the region.Of those polled In Bosnia and Herzegovina, 87\%think that the authorities are not invested in the fight against corruption. In Kosovo, 83\% think the same, while in Serbia, the poll returned $65 \%$.Essentially the positive dynamic of European reforms has faltered, and the dynamism is lost across the region and in the European Union." 47

Hundreds of thousands of youths from the countries of the former Yugoslavia have left, as the World Economic Forum data for 2016-17 shows. Almost 300,000 persons emigrated from Serbia between 2007 and 2014. The number of those who left in 2014 is double that from 2007, according to research from Vojvođanski istraživačko-analitički centar.

According to Vijesti newspaper research, 140,000 citizens out of a total population of 662,000 emigrated from Montenegro between 1991 and $2015 .^{48}$

\footnotetext{
${ }^{45}$ Jakubmarian.com, Current population, Data by United Nations, 2015

${ }^{46}$ Nspm.rs/hronika, 24 February 2021

${ }^{47}$ https://balcans.aljazeera.net/news/balkan/2016/6/21/svaki-drugi-stanovnik-regijeza-odlazak-u-eu

${ }^{48} \mathrm{https}$ ///balcans.aljazeera.net/interactives/2017/1/6/mapa-mladi-napuštaju-zemlje-regije
} 
The data shows a complete correlation between the intensity of SOE privatization and population emigration. In the observed period largest socially owned economic entities in Serbia and Montenegro were privatized. ${ }^{49}$

\section{The Case of Serbia}

Serbia (with its two autonomous provinces Vojvodina and Kosovo i Metohija), was one of the republics of the Socialist Federative Republic of Yugoslavia.

"The fastest economic growth in the world for some time was recorded in SFRY, under social ownership. The greatest achievement of self-management socialism was that it had quickly transformed former Yugoslavia from an obsolete and largely agricultural country to an industrialized and more developed economy and society compared to other socialist

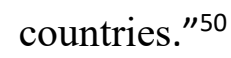

SFRY was ranked $31^{\text {st }}$ globally based on economic development.

After the dissolution of SFRY and the privatization of socially owned enterprises in the countries that emerged as SFRY successor states, dramatic economic decline ensued. 'Nationstates' in permanent stagnation replaced the prosperous Socialist Yugoslav self-managed society.

As the most developed republic of the SFRY, Slovenia had a GDP of 34,137 USD per capita in 1989. Thirty years later, none of the republics of the former Yugoslavia have managed to equalize their GDP from 1989. In Slovenia, GDP per capita is 24,597 USD, while in Serbia, it stands at 7,207 USD. The GDP in 1989 was 21,568 USD in Croatia, and 19,000 USD in Serbia, followed by Montenegro, Bosnia, Herzegovina, and Macedonia.

Italian expert Matteo Bonomi from Istituto Affari Internazionali believes that “...the countries from the Yugoslav region had accumulated a 97 billion EUR trade deficit with the EU

\footnotetext{
${ }^{49}$ Dr Marija Obradović, Dr Nada Novaković, "Is there the genuine influence of the trade union movement in the privatized companies in Serbia?", Social Movements in Central and Eastern Europe. A renewal of protest and democracy, edited by Ionel Nicu Sava, Geoffrey Pleyers, Editura Universitatii din Bucuresti, 2016.

${ }^{50}$ Isa Mulaj, "Redefining Property Rights with Specific Reference to Social Ownership in Successor State of Former Yugoslavia. Did it Matter for Economic Efficiency" Second Graduate Conference in Social Sciences The End of Transitions: Central and Eastern European Countries in Comparative Perspective, Central European University, Budapest, Hungary, 5-7May, 2006, p.6
} 
paralleled with the growth of their debt. At the same time, they receive aid from the accession funds in the range from 40 million EUR for Montenegro to 200 million EUR for Serbia which is not enough to balance the gap and enhance the development of the Western Balkans." ${ }^{\text {51 }}$

Factories producing the major brands Yugoslavia had exported to Europe and the rest of the world have disappeared. They were devastated in the process of privatization. They are:

Levi Strauss - Varteks Varaždin, Croatia; Lee Cooper - Beko Beograd, Serbia; Wrangler, Macedonia, Puma Borovo, Croatia; Adidas-Planika, Slovenia; Boss-Diorik Kragujevac, Serbia; Javor Ivanjica, Serbia; Police and military uniform production 22. Decembar; Elan, Slovenia; Kolinska, Slovenia; Podravka Koprivnica, Croatia; Roland raspberries; Zastava Kragujevac, Serbia; TAS Sarajevo, Bosnia and Herzegovina; IMV Novo Mesto, Slovenia; Cimos; "Peugeot Priština, Kosovo; IDA Kikinda, Vojvodina; FAP Priboj, Serbia; TAM Maribor, Slovenia; Ikarbus Zemun, Serbia; Tomos Kopar, Slovenia; FRAD Aleksinac, Serbia; HDT Ohrid, Macedonia; 21 Maj Beograd, Serbia; Jugoplastika Split, Croatia; Prvomajska Zagreb, Croatia; IMT Zemun, Serbia; Uljanik Shipbuilding Pula, Croatia; Obod Cetinje, Montenegro; Cer Čačak, Serbia; Rudi Čajevec Banja Luka, Bosnia and Herzegovina; Borac Beograd, Serbia; EI Niš, Serbia; Insa Zemun, Serbia; Tesla Pančevo, Serbia; TIZ Zagreb, Croatia; Match factory Rijeka, Croatia; Jugoagent, Vojvodina; Soko Mostar, Bosnia and Herzegovina; joint tank manufacturing in Slavonski Brod Croatia, Kragujevac and Beograd, Serbia; Jat Beograd, Serbia; Šipad Sarajevo, Bosnia and Herzegovina; Sloveniales, Lesnina, Meblo, Slovenia; Steel mills in Skoplje, Macedonia; Nikšić Montenegro, and Zenica Bosnia and Herzegovina; Aluminum smelting in Titograd, Montenegro, and Skoplje, Macedonia; Zinc plated steel sheet factory Vučitrn, Kosovo; Plastic film laminated steel sheet factory Sevojno, Serbia; Litostroj Ljubljana, Slovenia; Radoje Dakić Titograd, Montenegro.

More than 350,000 employees work for a minimal wage in Serbia, 32,126 RSD (272.2 EUR) per month, while half of the workforce receives less than the average wage, which net amount was 49,328 RSD (418.2 EUR) per month in March 2021. The average consumer goods cost is 74,892 RSD (632 EUR), while essential consumer goods cost is 38,354 RSD (323.6 EUR). The majority of workers are indentured laborers; that is to say, they do not have long-term employment prospects, while undeclared employment is widespread, particularly in the

\footnotetext{
${ }^{51}$ Blic, 24. 04. 2019; The term “Western Balkans"was first used in Executive Order 13219 by US President George W. Bush on the $26^{\text {th }}$ of June 2001 . The term encompasses the territory of the SFRY and the Republic of Albania.
} 
construction industry. Laborers work without job security, endure ill-treatment in the workplace, and receive derisive wages.

In 2016 employment in Serbia was at the same level as in 1977.

Table 2 Employment in the Republic of Serbia 1989-2016

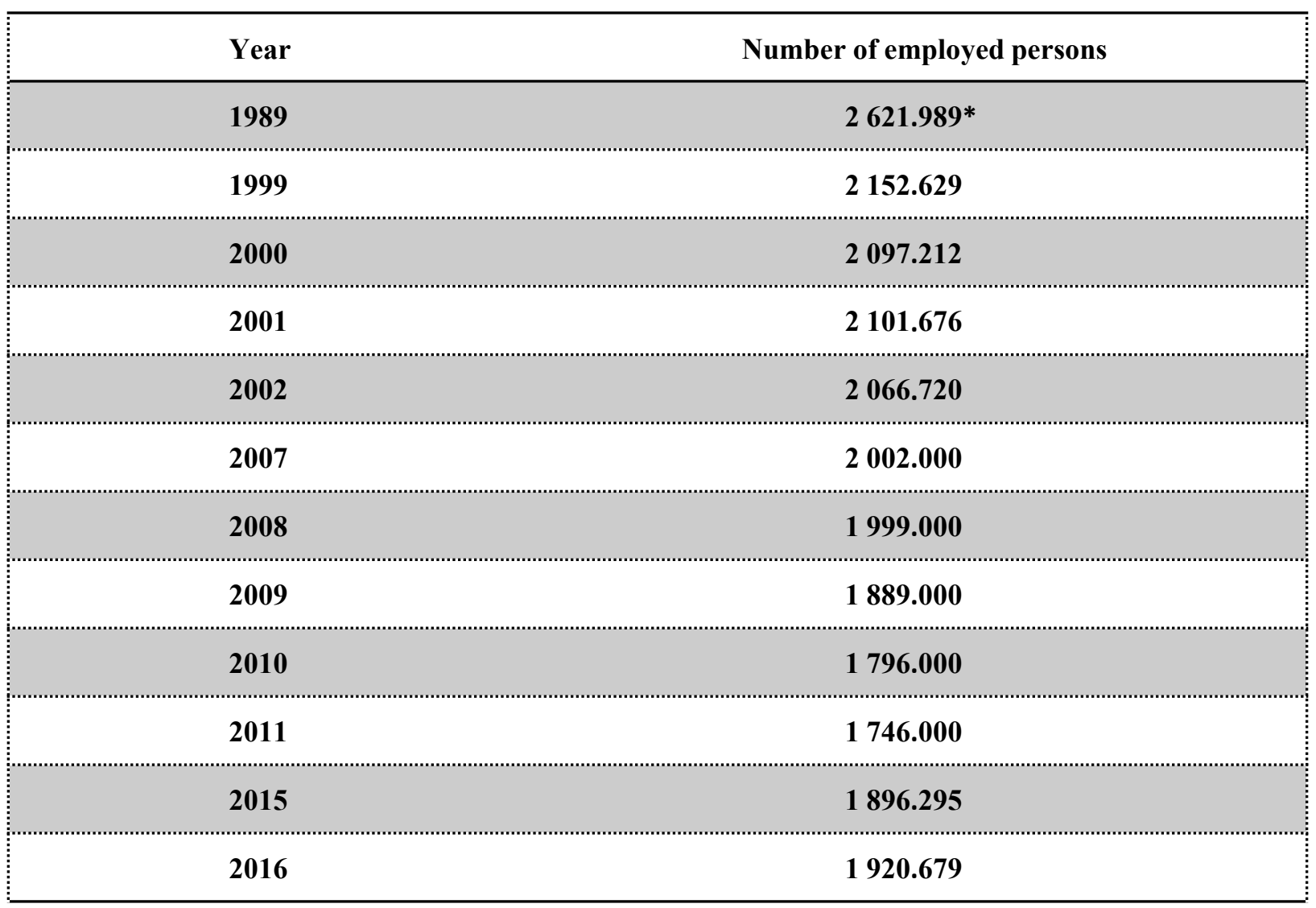

*Includes the figures for Kosovo $(237,298)$ subsequent years do not.

Source: Statistički godišnjak (Statistical Yearbook) Srbije i Crne Gore, Srbija i Crna Gora Zavod za statistiku, Beograd, 2003, p. 98; Statistički godišnjak (Statistical Yearbook), Republički zavod za statistiku, Beograd, 2012, p. 51; Statistički godišnjak (Statistical Yearbook) Republike Srbije 2017, Republički zavod za statistiku, Beograd, 2017, p. 64

Table 3 Chain indices* of nominal andtrue average net income (wages) in Republic of Serbia 19892014

\begin{tabular}{|ll|}
\hline Year & Index \\
\hline 1989 & 1800 \\
\hline 1990 & 529 \\
\hline 1991 & 210 \\
\hline
\end{tabular}




\begin{tabular}{|c|c|}
\hline 1992 & 4650 \\
\hline 1993 & $\ldots+$ \\
\hline 1994 & 422 \\
\hline 1995 & 203 \\
\hline 1996 & 188 \\
\hline 1997 & 146 \\
\hline 1998 & 132 \\
\hline 1999 & 120 \\
\hline 2000 & 189 \\
\hline 2001 & 225 \\
\hline 2007 & 127,9 \\
\hline 2008 & 118 \\
\hline 2009 & 108,8 \\
\hline 2010 & 107,6 \\
\hline 2012 & 109,0 \\
\hline 2013 & 106,2 \\
\hline 2014 & 101,4 \\
\hline 2015 & 99,8 \\
\hline 2016 & 103,7 \\
\hline
\end{tabular}

${ }^{*}$ Chain indices are relations of values in a preceding time interval resulting in an index for the given period expressed against the preceding period, depending on whether they are larger or lesser than 100 show relative growth, i.e., the drop of an observed value.

tDue to hyperinflation in 1993, the Statistical Office of the Republic of Serbia did not track salaries for this year.

Source: Statistički godišnjak (Statistical Yearbook) Srbije I Crne Gore, Srbija I Crna Gora Zavod za statistiku, Beograd, 2003, p. 106; Statistički godišnjak (Statistical Yearbook), Republički zavod za statistiku, Beograd, 2012, p. 62; Statistički godišnjak (Statistical Yearbook) Republike Srbije2017, Republički zavod za statistiku, Beograd, 2017, p. 76 
Graph 1 Account 3: Allocation of primary income account in the Republic of Serbia 2000-2014GDP, Wages, Profit

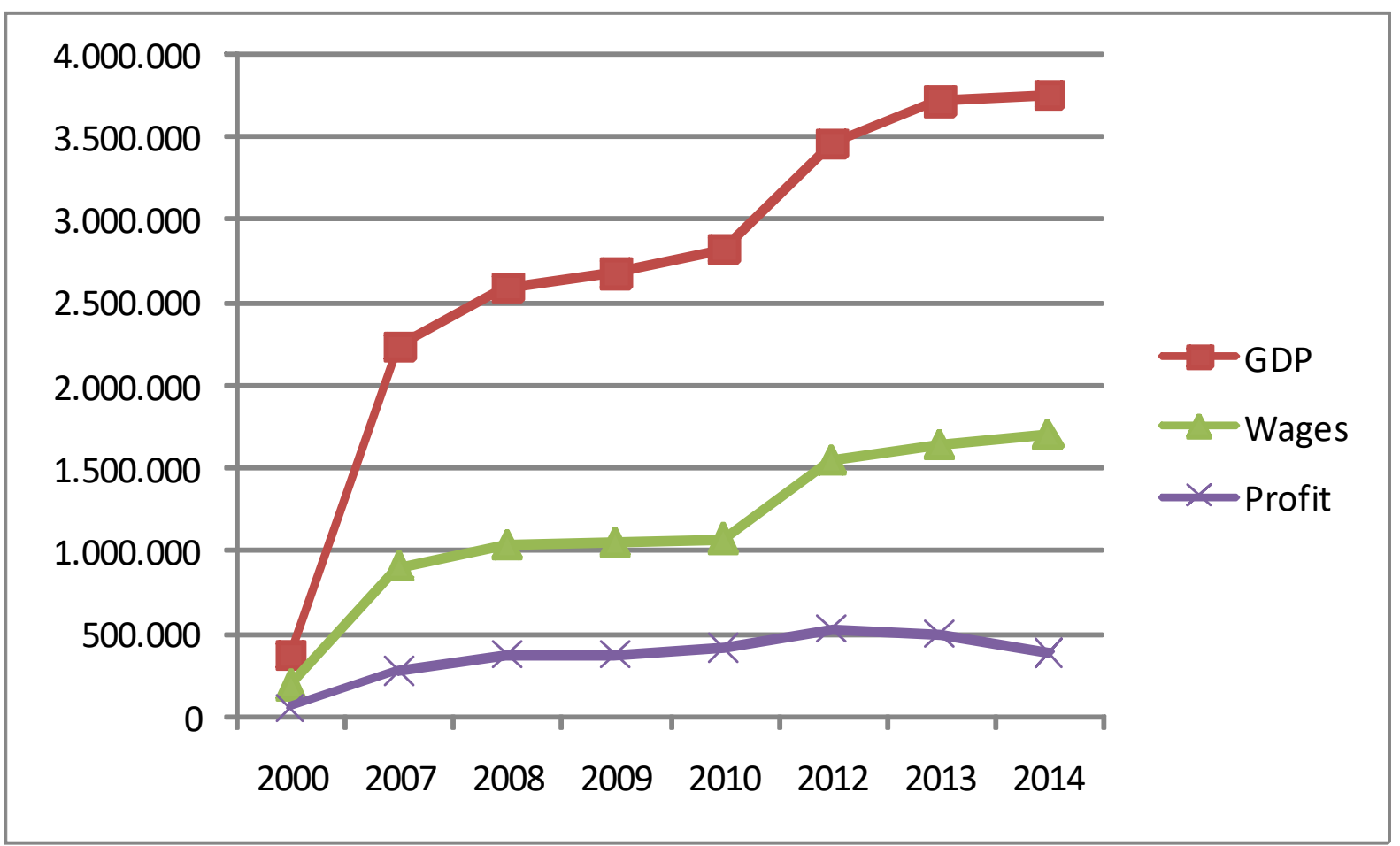

Source: Statistički godišnjak (Statistical Yearbook) Srbije i Crne Gore, Srbija i Crna Gora, Zavod za statistiku, Beograd, 2003, p. 116; Statistički godišnjak Statistical Yearbook), Republički zavod za statistiku, Beograd, 2012, p. 114; Statistički godišnjak Statistical Yearbook) Republike Srbije 2017, Republički zavod za statistiku, Beograd, 2017, p. 141 
Graph 2 GDP breakdown by employee income and ownership profit in the Republic ofSerbia 2000-

2014

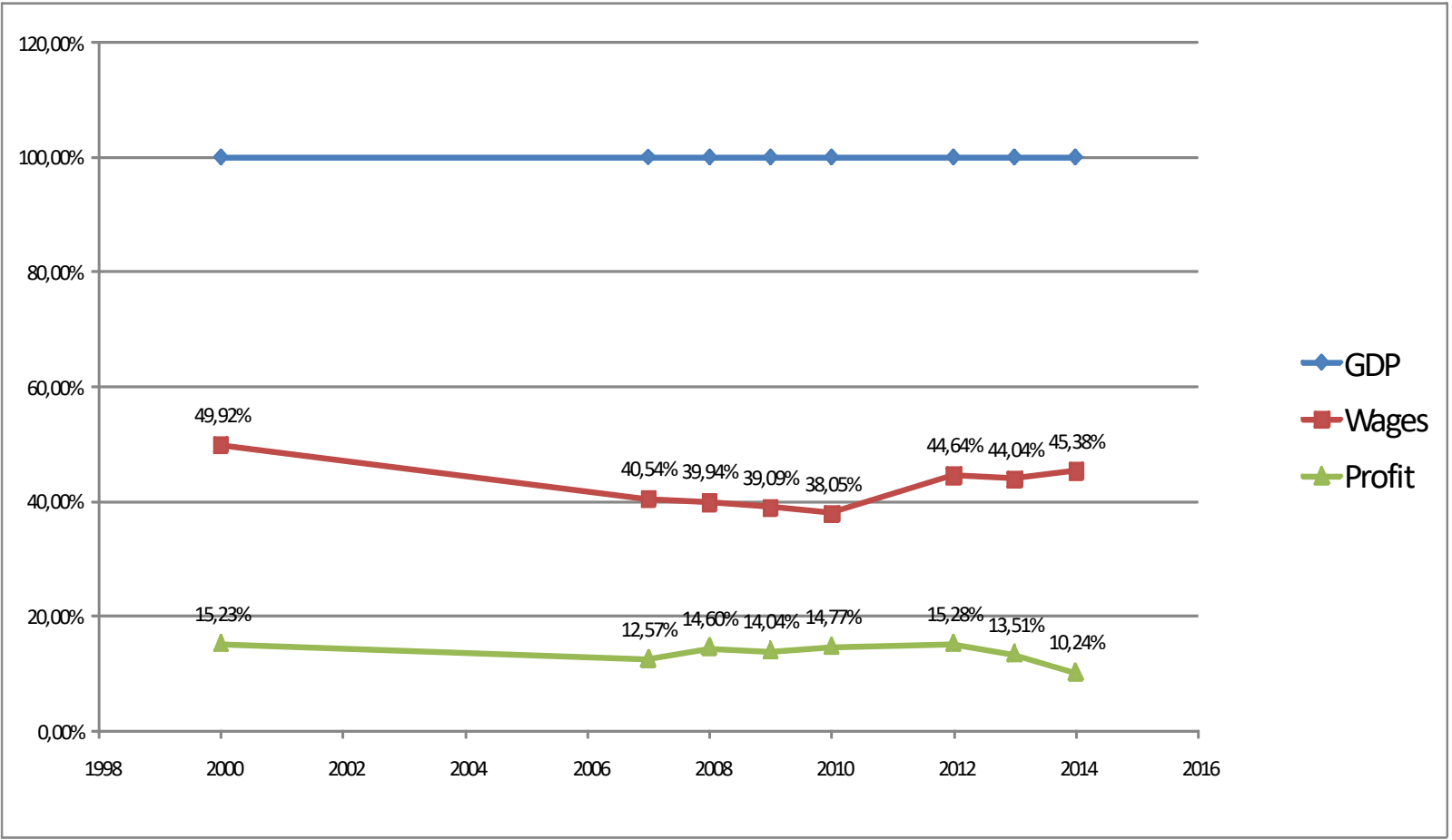

Source: Statistički godišnjak (Statistical Yearbook) Srbije i Crne Gore, Srbija i Crna Gora Zavod za statistiku, Beograd, 2003, p. 116; Statistički godišnjak, Republički zavod za statistiku, Beograd, 2012, p. 114; Statistički godišnjak (Statistical Yearbook) Republike Srbije 2017, Republički zavod za statistiku, Beograd, 2017, p. 141

The main feature of the economy of Kosovo is a persistent negative trend of macro-economic indicators, primarily the GDP, which is approx. 5, 5 billion USD, or around 3,084 USD per capita, according to Kosovo Agency Statistics, 2014. A rapid drop in the actual growth rate in Kosovo occurred after the 2008 declaration of independence when the privatization of SOEs accelerated. GDP growth per capita in Kosovo dropped from 4.5\% in 2008 to $1.2 \%$ in 2014 .

After the war in 1999, pursuant to the Law on Privatization in Kosovo, Law no. 03/L067, three processes of property transformation involving non-private properties were initiated: Commercialization process, through which 23 socially owned enterprises were commercialized;the privatization process involved around 500 SOEs; publicly owned enterprise restructuring process, such as ones in Kosovo Energy Corporation, Post and Telecommunications of Kosovo, Railways, Heating District, and other publicly owned enterprises. 
Since June 2002, the privatization process in Kosovo underwent two breaks, the first between the fourth quarter of 2003 and the first quarter of 2004. The process continued throughout 2005 to 2007 before a considerable second slow down during 2008.

The privatization process in Kosovo dealt with 500 socially owned enterprises (the most important were Trepča mines in Kosovska Mitrovica and the Ski Resort in Brezovica), of which only 30\% with around 60,000 employees were functioning after the war 1998-1999. Vital technical and human assets were concentrated in these enterprises during the 1980s in SFRY, "but because of the imposition of 'special measures' by the Serbian government and the violent governance and poor management during the 1990s; the depreciation of assets and technologies, and changes in the regional and international business environment most of these enterprises were operating inefficiently and below their capacities and many ceased operations altogether." 52

Albanians and other minorities who disagreed with Milošević's politics were forced out ofthe workplace at the Post and Telecommunication of Kosovo (PTK) by forceIn 1990. During the war, 1998-99, the office equipment and assets of the PTK were stolen, demolished, and some were completely destroyed.

By June 2014, 428 SOEs were tendered for sale in the form of 551 New Companies. And approximately 114 companies were undergoing liquidation. Total privatization proceeds were only 662 million EUR. Privatization triggered unemployment. The unemployment rate in Kosovo is the highest in the Yugoslav region, $45.0 \%$ in 2009 and $35.3 \%$ in $2014 .^{53}$

The number of employees and the rate of employment dropped in Serbia while unemployment rose. During the first decade of the transition, this was occluded due to furloughs. There were 3 million employed in 1992 and 1.3 million in 1993. The political shift after the 5th of October 2000 led to the abandonment of the furloughs. Persons working in the informal economy counted as employed.

Their share during the past two decades was about $20 \%$ of the employed totals. The actual number of those engaged in the informal economy was between 700,000 and 1 million.

\footnotetext{
52 Afrim Loku, Nadire Shehu Loku, „Privatising Socially Owned Enterprises, The Case of Kosovo, Asian Economic and Financial Review, 2016, 6 (5), p. 266

${ }^{53}$ Ibidem, p.p. 262,263, 267
} 
Serbia's total employment rate never went above $50 \%$ of the working-age population $149.7 \%$ in 2020), almost $10 \%$ below the EU 27 average. ${ }^{54}$

The total number of employees in the Republic of Serbia, who have a formal-legal employment contract, decreased in 2011 compared to 2010 by $2.8 \%$. The total number of employed women was $0.6 \%$ lower, while the total number of employed men decreased by $4.6 \%$. In legal entities (companies, enterprises, institutions, cooperatives, and other organizations), employment decreased by $0.9 \%$, and the number of entrepreneurs (unincorporated enterprises) - people who perform the activity independently, decreased by $8.6 \%$ in this period.

Observed by regions and comparing 2011 with 2010, the most significant employment decrease was noted in the region of Belgrade (3.4\%).

The average salary of those employed in legal entities and unincorporated enterprises in the Republic of Serbia, in 2011 compared to 2010, registered a nominal increase of $11.1 \%$ and an actual increase of $0.1 \% .^{55}$

The Kosovo 2012 Labor Force Survey results (2013) show that around 1.2 million, or twothirds of the total population, from the working-age group (people aged $15-64$ ). Of the total working-age group, only 36.9 percent are active in the labor force $(438,544$ people). Out of the total number of those active in the labor force, $69.1 \%(302,844$ people) were employed, and $30.9 \%$ were unemployed (135,700 people). Unemployment is much higher for women $(33.1 \%)$ than men $(41.6 \%)$. The most discouraging figure is the youth unemployment rate $(15-24)$, the highest among all age groups at $55.3 \%$. Around $63.8 \%$ of young females and $52.0 \%$ of young males in the labor force were unemployed.

Moreover, the generally high rate of unemployment has led to a high poverty rate. Approximately $34.5 \%$ of the population In Kosovo lives in poverty, and around $12.2 \%$ live in extreme poverty with less than 1 euro per day. ${ }^{56}$

\footnotetext{
${ }^{54}$ Jandrić Maja i Dejan Molnar, Kvalitet zaposlenosti i tržište rada u Srbiji. Koliko smo stvarno udaljeni od EU?, Friedrich Ebert Stiftung, Beograd, 2017, p. 8, Anketa o radnoj snazi, IV kvartal 2020, Republočki zavod za statistiku, Beograd, 2021, p. 4

${ }^{55}$ Statistički godišnjak ( Statistical Yearbook), Republički zavod za statistiku, Beograd, 2012, p.p. 31,32, 47

56 Afrim Loku, Nadire Shehu Loku, „Privatizing Socially Owned Enterprises, The Case of Kosovo, Asian Economic and Financial Review, 2016, 6 (5), p. 261, 262.
} 
During the 1980s, there was no registered poverty in the SFRY. Nevertheless, around half a million Serbian citizens, or $7.2 \%$, live below the absolute poverty level on less than 100 euros per month.

Official data on absolute poverty in Serbia concludes that there has not been any significant poverty reduction in the period from 2006 to $2016 .{ }^{57}$ When the population at risk from poverty is considered, Serbia is in the top spot (24.6\%) out of 34 countries, according to Eurostat data for 2017. The EU 28 average was 16.3 \%, in Croatia it is $19.7 \% .20 .2 \%$ in Macedonia, $23.4 \%$ in Bulgaria, 21.5 \% in Romania, 13.3 \% in Slovenia and $8.6 \%$ in the Czech Republic. ${ }^{58}$ The risk of poverty was higher Serbia and the region, particularly among the unemployed and the youth. A contributing factor was the global economic crisis, but transition and privatization contributed even more. ${ }^{59}$

Soup kitchens in Serbia (Kosovo excluded) feed around 35,000 people; meals for 12,000 are provided in Belgrade soup kitchens. The report of the Social Inclusion and Poverty Reduction Unit of the Government of the Republic of Serbia stipulates that "almost two-thirds of $63.9 \%$ of Serbia's population is subjectivelypoor. When households are asked whether they 'make ends meet,' the families answer, 'the situation is tough' and 'it is exceedingly difficult." 60

According to UNICEF around $30 \%$ of children in Serbia live on the verge of poverty, whereas every tenth child lives in absolute poverty. ${ }^{61}$

The Network of Organizations for Children of Serbia (MODS) claims that around 400,000 children in Serbia are at risk of poverty. Due to high-incomeinequality, many families in Serbia live on approximately 250 EUR per month. ${ }^{62}$

\footnotetext{
57 Biljana Mladenović, Siromaštvo u Republici Srbiji 2006-2016 godine. Revidirani i novi podaci, Tim za socijalno uključivanje i smanjenje siromaštva Vlade Republike Srbije, Beograd, avgust 2017, p.14

${ }^{58} \mathrm{ec} /$ europa/eurostat/statistics

${ }^{59}$ Nada G. Novaković, Radnički štrajkovi i tranzicija u Srbiji od 1990. do 2015. godine, Rosa Luxemburg Stiftung Southeast Europe, Institut društvenih nauka, Beograd, p.131.

${ }^{60}$ Blic.rs/vesti, 28 October 2018

${ }^{61}$ Nspm.rs/hronika, 20 November 2018

${ }^{62}$ Nspm.rs/hronika, 17 October 2018
} 


\section{Changes to population structure in Serbia 1989-2020}

Population reduction increased during the transition in Serbia. According to official data, the population of Serbia was $9,590,000$ in 1989 , growing to $9,969,000$ in 1995. Population dropoccurred in 2000 . There were $6,945,000$ citizens in 2019 , a reduction of $27 \%$ or $2,545,000$ compared to 1989 (see Graph 3). Estimates show that the population in Serbia will drop to its 1960 level in 2040.

\section{Graph 3}

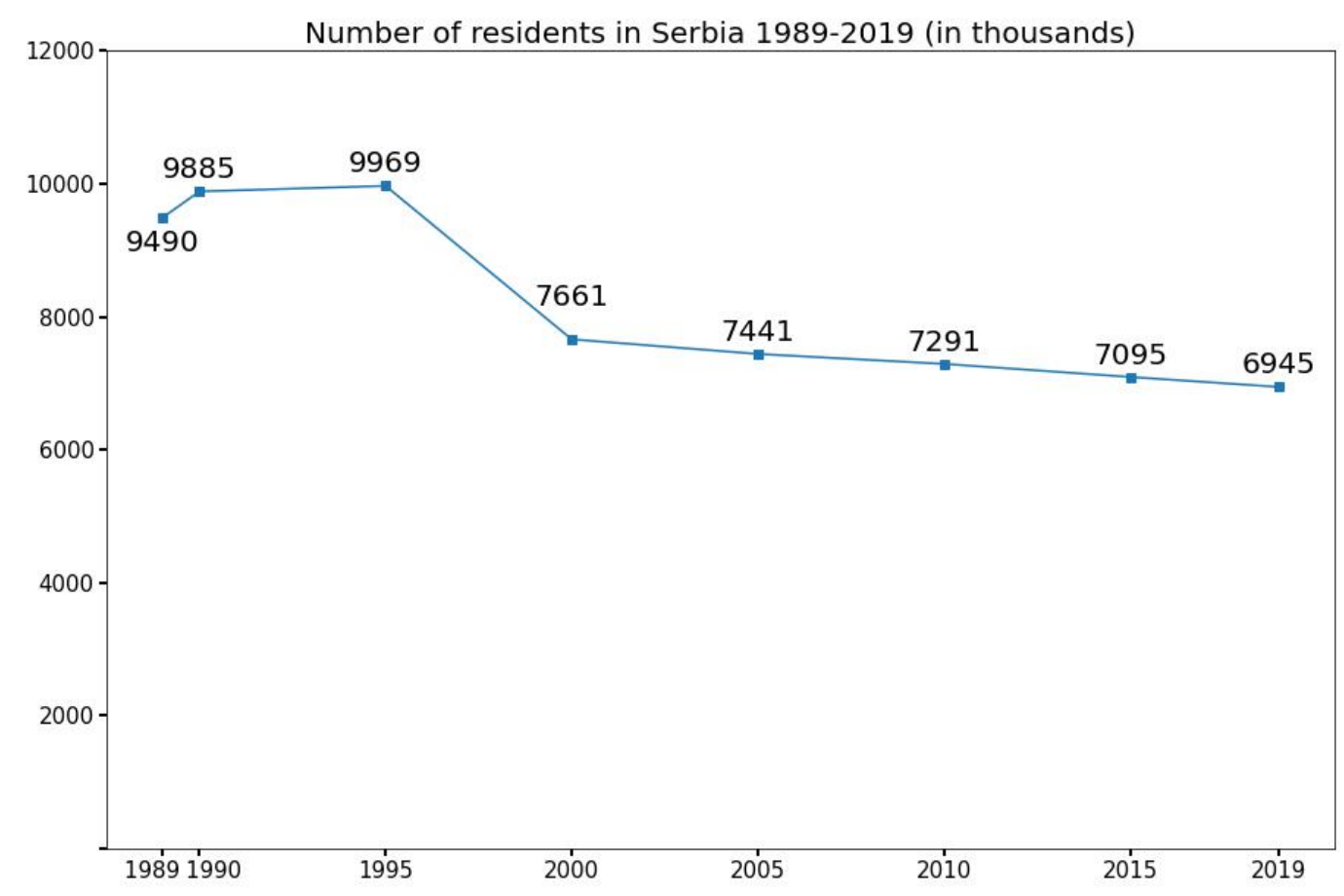

Source: Statistički godišnjak (Statistical Yearbook) Jugoslavije 1991, Savezni zavod za statistiku, Beograd, 1991, p. 442; Statistički godišnjak (Statistical Yearbook) Srbije 1997, Republički zavod za statistiku, Beograd, 1997, p. 38; Statistički godišnjak (Statistical Yearbook) Srbije 2003, Republički zavod za statistiku, Beograd, 2003, p. 37; Statistički godišnjak (Statistical Yearbook) Srbije 2004, Republički zavod za statistiku, Beograd , 2004, p. 58; Statistički godišnjak (Statistical Yearbook) Srbije 2007, Republički zavod za statistiku, Beograd, 2007, p. 75; Statistički godišnjak (Statistical Yearbook) Srbije 2011, Republički zavod za statistiku, Beograd, 2011, p. 31; Statistički godišnjak (Statistical Yearbook) Srbije 2020, Republički zavod za statistiku, Beograd, 2020, p. 37. 
There were many contributing factors: wars during the break-up of SFRY, emigration, privatization, declining marriage rates, postponement of childbearing, low birth rates, a declining standard of living, and a terrible population age structure. This population reduction trend is known as depopulation in demographics, and it became acceleratedduring the last three decades in Serbia, as evidenced by the annual natality and mortality rates (see Graph 4;per 1000 population).

\section{Graph 4}

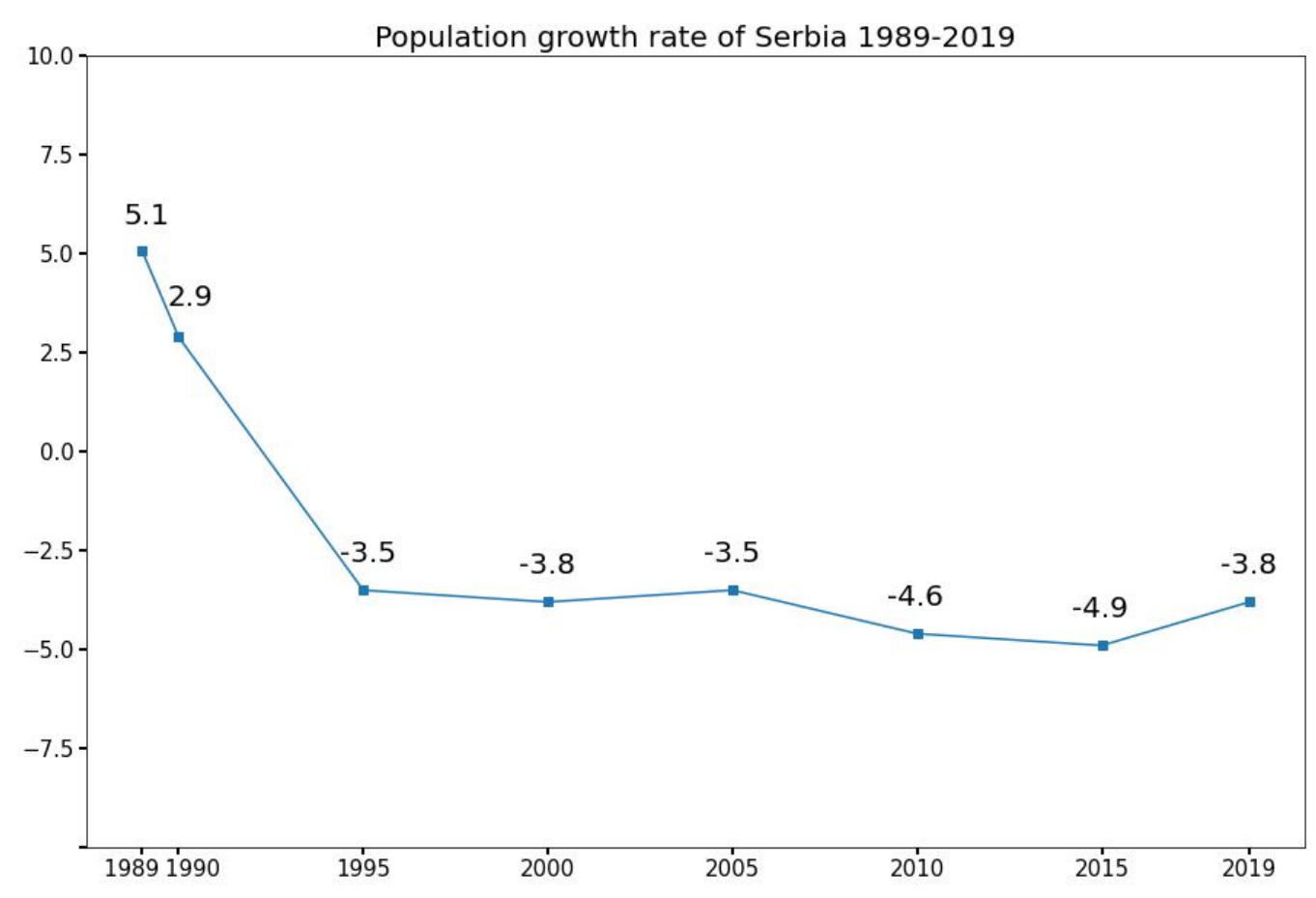

Source: Statistički godišnjak (Statistical Yearbook) Jugoslavije 1991, Savezni zavod za statistiku, Beograd, 1991, p. 442; Statistički godišnjak (Statistical Yearbook) Srbije 1997, Republički zavod za statistiku, Beograd, 1997, p. 38;Statistički godišnjak (Statistical Yearbook) Srbije 2003, Republički zavod za statistiku, Beograd, 2003, p. 37; Statistički godišnjak (Statistical Yearbook) Srbije 2004, Republički zavod za statistiku, Beograd , 2004, p. 58; Statistički godišnjak (Statistical Yearbook) Srbije 2007, Republički zavod za statistiku, Beograd , 2007, p. 75; Statistički godišnjak (Statistical Yearbook) Srbije 2011, , Republički zavod za statistiku, Beograd, 2011, p. 31;Statistički godišnjak (Statistical Yearbook) Srbije 
2020, ; Statistički godišnjak (Statistical Yearbook) Srbije 2020, , Republički zavod za statistiku, Beograd, 2020, p. 37.

A decline in the number of live births in Serbia started before the transition but was accelerated by it. While this is partly due to social and economic changes from the early 1990s, it is an implicit indicator of the living conditions in which the reproductive population found itself during the past three decades. The number of live births was 144,926 in 1989. By the next decade, it was almost halved to 72,222 . In 2019 , it dropped to 64,339 . The figure is 80,257 or $44.4 \%$ less than it was in 1989 and lower than any in the XX century. Accordingly, the number of live births per 1000 population (fertility rate) declined. In the past twenty years, the fertility rate never went above 10.0, falling from 14.7 in 1989 to 9.3 at the end of $2019 .{ }^{63}$

A fertility rate below 10.0 was found in 129 municipalities from 2002 and 2011, limiting the simple population replacement. By that, Serbia is similar to other countries of the Balkans. ${ }^{64}$

The population underwent accelerated mortality, indicated by annual figures of over 100,000 after 1994. At the same time, the mortality rate (number of deaths per 1000 population) was over 10.0. In the last decade, the mortality rate remained high at 14.0. In 2019 the mortality rate was 14.6 compared to the 9.7 rate in $1989 .{ }^{65}$

\section{Mortality rate increases, and birth rate decline in Serbia compared to the SFRY era}

\footnotetext{
${ }^{63}$ Izvor: Statistički godišnjak (Statistical Yearbook) Jugoslavije 1997, Savezni zavod za statistiku, Beograd,1997 Beograd, 1997, p. 38; Statistički godišnjak (Statistical Yearbook) Srbije 2003, Republički zavod za statistiku, Beograd, 2003, p. 37; ;Statistički godišnjak (Statistical Yearbook) Srbije 2005, Republički zavod za statistiku, Beograd, 2005, p. 69; Statistički godišnjak (Statistical Yearbook) Srbije 2006, Republički zavod za statistiku, Beograd, 2006, p. 67; Statistički godišnjak (Statistical Yearbook) Srbije 2020, Republički zavod za statistiku, Beograd, 2020, p. 37

${ }^{64}$ Goran Penev, „Novije promene u populacionoj politici Srbijeibalkanskihzemalja”, Demografija, vol VII, Beograd, 2010, p. 10

${ }^{65}$ Izvor: Statistički godišnjak (Statistical Yearbook) Jugoslavije 1997, Savezni zavod za statistiku, Beograd,1997, Beograd, 1997, p. 38; Statistički godišnjak (Statistical Yearbook) Srbije 2003, Republički zavod za statistiku, Beograd , 2003, p. 37; Statistički godišnjak (Statistical Yearbook) Srbije 2005, Republički zavod za statistiku, Beograd , 2005, p. 69; Statistički godišnjak (Statistical Yearbook) Srbije 2006, Republički zavod za statistiku, Beograd , 2006, p. 67; Statistički godišnjak (Statistical Yearbook) Srbije 2020, Republički zavod za statistiku, Beograd, 2020, p. 37
} 
"The Serbian mortality rate is among the highest in Europe. At present, in Serbia annually die 35,000 to 38,000 more people than they are born. In the 1950s, 160,000 children were brought into this world per year in Serbia, whereas today, 100,000 fewer children are born. In the 1950 s, around 60,000 people died annually, whereas today, 100,000 people are dying". ${ }^{66}$

Recent data on the number of deceased in 2020 points to the severity of the problem. According to the Statistical Office of the Republic of Serbia data (RSZ), 53,261 more deaths than live births in 2020 . There were 61,693 live births for 114,954 deaths. The number of deceased increased by $13.9 \%$ over the 2019 figure, and the number of live births dropped by 2.8 \%. There were $58.2 \%$ more deaths in March 2021 (12,952 deceased) than in the same month of 2020. The total number of deaths for the first quarter of 2021 is 33,535 , or 7,518 more deaths for the same period in 2020 , an increase of $28.9 \% .{ }^{67}$

Official COVID-19 figures for June 2021 for the Republic of Serbia record 712,702 cases of infection with the virus. The mortality rate was $0.96 \% .{ }^{68}$

Mortality data present indirectly fundamentally changed living conditions during the transition in Serbia. High mortality is caused not only by wartime activity but incrementally worse medical care. The neoliberal concept of health system funding, social care, and education considers these as a 'cost' in need of cutting.

Natural increase is the difference in value between the number of live births and deaths over a period in time in a particular territory. In the last three decades in Serbia, it has steadily declined. Initially, the population growth rate (natural increase per 1000 population) dropped to 2.9 in 1990 from 5.1 in 1989. Negative growth rates followed, i.e., the number of deceased exceeded the number of live births.

\footnotetext{
${ }^{66}$ Ivan Marinković, Politika, 6 November, 2018

${ }^{67}$ Nspm.rs/hronika, 26 April, 2021

${ }^{68}$ Ibidem, 1 June, 2021
} 
Table 4 Population growth rate in Serbia 1989-2019

\begin{tabular}{|c|c|c|c|c|c|c|c|c|}
\hline & 1989 & 1990 & 1994 & 1999 & 2004 & 2009 & 2014 & 2019 \\
\hline $\begin{array}{c}\text { Population } \\
\text { growth }\end{array}$ & 49489 & 51913 & -12634 & -29222 & -26134 & -34907 & -34786 & -37059 \\
$\begin{array}{c}\text { Population } \\
\text { growth } \\
\text { rate/per } \\
1000\end{array}$ & 5,1 & 2,9 & $-3,5$ & $-3,8$ & $-3,5$ & $-4,6$ & $-4,9$ & $-3,8$ \\
\hline \begin{tabular}{c} 
population \\
\hline
\end{tabular}
\end{tabular}

Source: Statistički godišnjak Srbije (Statistical Yearbook) 1997, Republički zavod za statistiku, Beograd, 1997, str. 38; Statistički godišnjak Srbije (Statistical Yearbook) 2003, Republički zavod za statistiku, Beograd, 2003, p. 37; Statistički godišnjak Srbije(Statistical Yearbook) 2005, Republički zavod za statistiku, Beograd, 2005, p. 69; Statistički godišnjak Srbije (Statistical Yearbook) 2006, Republički zavod za statistiku, Beograd, 2006, p. 67; Statistički godišnjak Srbije(Statistical Yearbook) 2020, Republički zavod za statistiku, Beograd, 2020, p. 37

\section{Graph 5}

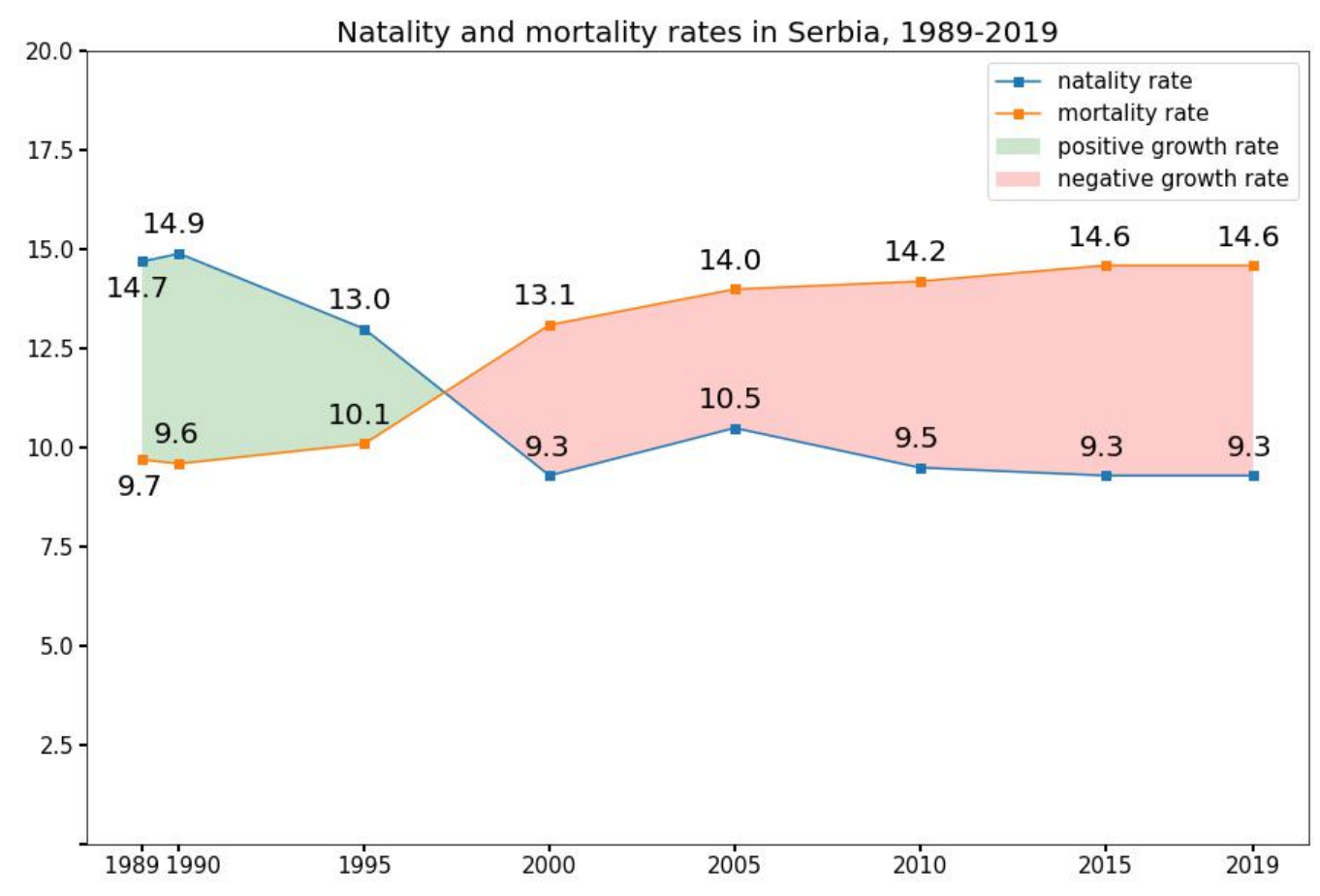

Source: Statistički godišnjak (Statistical Yearbook) Jugoslavije 1997, Savezni zavod za statistiku, Beograd,1997, Beograd, 1997, p. 38; ;Statistički godišnjak (Statistical Yearbook) 
Srbije 2003, Republički zavod za statistiku, Beograd , 2003, p. 37; Statistički godišnjak (Statistical Yearbook) Srbije 2005, Republički zavod za statistiku, Beograd, 2005, p. 69;Statistički godišnjak (Statistical Yearbook) Srbije 2006, Republički zavod za statistiku, Beograd, 2006, p. 67; Statistički godišnjak (Statistical Yearbook) Srbije 2020, Republički zavod za statistiku, Beograd, 2020, p. 37

Serbia started losing between 12,000 and 35,000 citizens annually in the mid-1990s. It was a precipitous fall from growth of 51,913 in 1990 to a loss of 53000 in 2020 . The population growth rate was 2.9 in 1990 and -5.3 in 2020. Serbia has the lowest population growth rate out of all the successor states of SFRY.

The simple replacement rate requires that, on average, every woman of reproductive age (1549) bears 2.1 children. The total fertility rate,i.e., number of children born by a single woman, the declined in Serbia even before the transition began. In the period from 1990 to 2020, fertility was not high enough to provide generation replacement. From 1991 onwards, the general fertility rate declined (1.73) and was down to 1.4 , settling to that level in $2019 .{ }^{69}$

Low fertility is characteristic of other Eastern European countries. According to Eurostat data, all these countries have fertility rates lower than the EU average (1.57). The more developed EU countries show slightly more favorable figures (France 1.96; Sweden 1.85;) while not a single EU member managed the 2.1 rate. In Serbia it was 1.44; Croatia 1.40; Montenegro 1.33; Poland 1.32; and 1.58 in Romania. ${ }^{70}$

Unlike Western Europe, with its demographically old population, the Eastern European countries find themselves in an unfavorable position. Their populations are slow to replenish, faster at emigrating, aging, and dying. The age of the female population is not the only contributing factor; historical, cultural factors, more extended education periods, and difficulties in balancing work and family roles.

Viewed under UN demographic criteria, the Serbian society is classed as old, being the third eldest in Europe. ${ }^{71}$ The share of the population 65 years and over is above 7 \%. In 1991 that

\footnotetext{
${ }^{69}$ Goran Penev, „Fertilitet Republike Srbije u sklopuširegevropskogokruženja”, Demografskipregled, br. 4, 2000, Statistički godišnjak (Statistical Yearbook) Srbije 2020, Republički zavod za statistiku, Beograd, 2020, p. 51

${ }^{70}$ Lara Lebedinski, mons.rs/demografske-promene, October 15, 2018.

71 UN, World Population Prospects, The 2015 Revision, Key Findings and Advance Tables, Working Paper No ESA/P/WP.241, New York, 2015.
} 
share was $11.9 \% ; 21.5 \%$ in 2015 , and $25.4 \%$ in 2019 . Every fifth person in the eldest population group was over 80 years old. ${ }^{72}$

At the same time, the number of children up to 14 years of age fell in the population overall. At the beginning of the period from 1991 to 2019, their share of the population was $19.4 \%$, dropping to $14 \%$ at the end. The estimates show that this group will have a $14.3 \%$ share in 2040, while those over 65 will represent $31.4 \%$ of the population. ${ }^{73}$

Consequently, this means smaller groups of pre-school age (0-6) and schoolchildren (7-14), which will have repercussions on education policy. The increase of the share of the eldest citizens creates demand for funding for the pension system, health care, and social services.

Other indicators of the demographically aging population are median age and aging index. Each is calculated separately for the total population and both sexes.

We provide data for the total population. To summarize, the median age indicates the main flow of change of the age structure. The median age has increased significantly. The total population median age was 37.5 years in 1991, rising to 39.9 in 2001. Ten years later, it was 42.1 reaching 43.3 years in $2019 .^{74}$

The aging index is the ratio of the elderly (60 years and above) and the youth (0 to 19 years). The official statistics in Serbia tell us that the country'spopulation is undergoing intensive aging. The aging index had more than doubled since 1991 from 69.0 to $144.1 .^{75}$

Like other countries of Eastern Europe, Serbia is characterized by intensified aging of the population, more rapid than in Western Europe, and a more rapid total population decline. UN estimates that Bulgaria will experience the most significant population decline $(27.9 \%)$ and Malta the least (1.8\%). By that year, Serbia will lose $17.2 \%$ of its population. The primary

\footnotetext{
72 Goran Penev, „Strukture stanovništva premapoluistarosti”, u PopulacijaSrbije početkom 21. veka, (ured. Vladimir Nikitović), Zavod za statistiku Republike Srbije, Beograd, 2015, p. 143, Statistički godišnjak (Statistical Yearbook) Srbije 2015, ), Republički zavod za statistiku, Beograd, 2015, p. 35, Statistički godišnjak (Statistical Yearbook) Srbije 2020, Republički zavod za statistiku, Beograd, 2020, p.38

${ }^{73}$ Statistički godišnjak (Statistical Yearbook) Srbije 2020, Republički zavod za statistiku, Beograd, 2020, p. 38

${ }^{74}$ Statistički godišnjak (Statistical Yearbook) Srbije 2004, Republički zavod za statistiku, Beograd, 2004, p. 58, Statistički godišnjak (statistical Yearbook) Srbije 2020, Republički zavod za statistiku, Beograd, 2020, p. 37

${ }^{75}$ Statistički godišnjak (Statistical Yearbook) Srbije 2004, Republički zavod za statistiku, Beograd, 2004, p. 58, Statistički godišnjak (statistical Yearbook) Srbije 2020, Republički zavod za statistiku, Beograd, 2020, p. 37
} 
causes are low birth rates and rapid aging; in effect: "There is no country in this part of the world that will not have to face a population decline." 76

Migrations only partially disrupt this type of population structure. In the past three decades, they were propelled by wars, privatization, transition, and ancillary problems caused by globalization. More than 8.6 million people left the Balkans, 50 \% of whom were from the SFRY and especially Serbia. Emigration estimates for Serbia diverge. OSCE data for regional migration is for the period from 1990 to 2019. Since 2000, there were 645,000 departures from Serbia; the number rises to $1,154,000$ when we observe the period from 1989. A significant portion of these were the most educated individuals. ${ }^{77}$

The latest research shows that two-thirds of youth want to emigrate from Serbia, and $81.9 \%$ stated economic conditions as the primary motivation.

Emigration appetite is significantly higher in our country compared to the region. ${ }^{78}$ The departure of the younger generation, males in particular, additionally worsened the demographic structure in Serbia.

The socio-economic structure of the population had also changed. In the observed period from 1991 to 2020, the active working population aged 15 and above increased insignificantly from $52 \%$ to $55 \%,{ }^{79}$ which is $15 \%$ less than the EU average.

The Serbian population is demographically old by all crucial characteristics; data on median age, aging index, and dependence index indicate this, and the general direction of changes is depopulation or population decline.

The critical factor driving this is the decades-long collapse of natural increase. The population replacement by natural means is inadequate due to low fertility, while aging is intensifying,

\footnotetext{
${ }^{76}$ Душан Пророковић, „Демографски трендови у ецропским државама: Кадепопулацијиперифериејконтинента”, Култураполиса,година ХІХ, посебно издање, 2017, пп. 174-185

${ }^{77}$ A. Milutinović, Blic.rs/vesti, August 26, 2019

${ }^{78}$ Dragan Popadić, Zoran Pavlović, Srećko Mihailović, Mladi u Srbiji 2018/2019, Frierich Ebert Stiftung, Beograd, 2019, p. 36

79 Biljana Radivojević, „Ekonomske structure stanovništva” u Populacija Srbije početkom 21. veka, urednik Vladimir Nikitović, Republički zavod za statistiku, Beograd, p. 224; Anketa o radnoj snazi, IV kvartal 2020, Republički zavod za statistiku, Beograd, 2021, p. 4
} 
and mortality increases. Compared to the region and Eastern Europe, this is a feature of Serbia alone.

Demographic collapse is already here, and the UN estimates show it continuing until 2050. The total population will be reduced by $15 \%$, while Eastern Europe will drop by $13 \%$ on average. Emigration is a critical factor in these changes, reducing the population by $5 \%$. Fertility rates are too low for generational replacement and will drop even further as the country's population ages rapidly, and emigration continues.

Serbia's existing population structure is a consequence of economic, political, and historical changes, presenting a formidable limiting factor to economic and social progress. Current public policy based on the neoliberal concept of development contributed more to negative demographic trends than it ever did to their mitigation or remediation.

If we only look at employment, pensions, health, and social care, all degraded compared to levels preceding transition and privatization of the socially-owned capital;for the majority, the outcomes were reduced benefits, lower standards of care, precarious compensation, and other income losses.

\section{Conclusion}

Globalization and large-scale privatization did not bring prosperity to the post-communist countries of Eastern Europe. The main socio-economic consequences of the historical process in these countries are the pauperization of the entire working class and significant population decline. If we can say that the international financial capital is globalization's winner, the Eastern European working class is its biggest loser.

Societies with full-blown inequality do not operate efficiently; therefore, their economies are neither stable nor sustainable. Inequality always slips into economic inefficiency. Research by the International Monetary Fund has shown that egalitarian societies are also economically more successful - they achieved higher economic growth and are far more stable.

The preceding fact is reflected in the development of Yugoslavia's successor states post disintegration of SFRY and its self-managed economic-political, social system, and large-scale privatization of socially owned enterprises, Serbia in particular. 
To this day, no ex-Yugoslav republic has reached GDP per capita from 1989.

'Nation-states' in permanent stagnation replaced the prosperous Socialist Yugoslav selfmanaged society.

The cardinal consequences of the historical processes of globalization and privatization in Eastern Europe are significant deterioration of labor relations, brutal exploitation accompanied by pauperization of the working class, poverty, and depopulation.

The financial sector conducts the exploitation through market manipulation. 